This item was submitted to Loughborough's Research Repository by the author.

Items in Figshare are protected by copyright, with all rights reserved, unless otherwise indicated.

\title{
The form of relationship between firm-level product innovativeness and new product performance in developed and emerging markets
}

\section{PLEASE CITE THE PUBLISHED VERSION}

http://dx.doi.org/10.1111/jpim.12180

\section{PUBLISHER}

Wiley () Product Development \& Management Association

\section{VERSION}

AM (Accepted Manuscript)

\section{PUBLISHER STATEMENT}

This work is made available according to the conditions of the Creative Commons Attribution-NonCommercialNoDerivatives 4.0 International (CC BY-NC-ND 4.0) licence. Full details of this licence are available at: https://creativecommons.org/licenses/by-nc-nd/4.0/

\section{LICENCE}

CC BY-NC-ND 4.0

\section{REPOSITORY RECORD}

Story, Victoria, Nathaniel Boso, and John Cadogan. 2014. "The Form of Relationship Between Firm-level Product Innovativeness and New Product Performance in Developed and Emerging Markets". Loughborough University. https://hdl.handle.net/2134/17716. 


\title{
The Form of Relationship between Firm-level Product Innovativeness and New Product Performance in Developed and Emerging Markets
}

\begin{abstract}
This study investigates whether the relationship between firm-level product innovativeness and new product performance is curvilinear, and whether the nature of this relationship is dependent on organizational and environmental factors in both developed and emerging market contexts. Using primary data from 319 UK and 221 Ghanaian companies, this study shows that in both developed and emerging markets the basic form of the relationship between firm-level product innovativeness and business success is inverted U-shape, but that the strength and/or form of this relationship changes under differing levels of market orientation, access to financial resources, and environmental dynamism. Some commonalities are identified across the two countries: market orientation helps firms leverage their product innovativeness. However, differences are also observed across the samples: in Ghana, access to financial resources enhances the relationship between product innovativeness and new product performance, unlike in the UK, where access to financial resources has no significant impact on this relationship. Furthermore, while UK firms are able to leverage product innovativeness to their advantage in more dynamic environments, Ghanaian firms are not able to benefit in this way, and find that high levels of innovation activity are less useful when markets are more dynamic.
\end{abstract}

Keywords: firm-level product innovativeness, product innovation intensity, product innovation novelty, new product performance, firm-specific resources, environment, developed markets, emerging markets 


\section{Introduction}

Organizational ability to innovate is a key determinant of survival and success and, as such, receives significant literature attention (e.g., Sandvik and Sandvik, 2003). However, the competitive landscape is changing through globalization, increasing competition worldwide (Sun and Lee, forthcoming), and emerging market growth opportunities (Cavusgil et al., 2002). In rapidly changing markets that require firms to increase their innovation activity, conventional wisdom is that major innovation activities are predominantly undertaken in developed economies (Luo et al., 2011), and that developed market firms do better than their emerging market counterparts because of the superiority of the former's business-supporting institutions and technological competencies (Luo and Tung, 2007).

However, emerging market economies continue to out-grow developed economies (Luo and Tung, 2007), such that emerging economies now constitute eight out of the eleven most attractive locations to do business (UNCTAD, 2012; p. 29). Meanwhile, dramatic increases in the number of new products introduced by emerging market firms in recent years have also captured scholars' attention (Sun and Lee, forthcoming). These developments create opportunities for innovation researchers to further examine innovation activities in and from emerging markets. Currently, what is not yet clear is how the performance outcomes of emerging market firms' innovation strategies compare with those of developed market firms. Firm-level product innovativeness is an important determinant of firm success (Calantone et al., 2003; Tajeddini et al., 2006), and firms need to understand the return on investment (ROI) implications of innovation activities (Özçelik and Taymaz, 2004). Developing knowledge regarding the performance outcomes of internal resources and external firm-level environment factors requires a firm-level approach to product innovativeness.

In this context, although research almost exclusively highlights a positive link between firm-level product innovativeness and firm success, researchers still argue that the exact nature of the latter relationship is, as yet, unclear (e.g., Droge et al., 2008; Kyrgidou and Spyropoulou, 2012). Furthermore, research on a product-level U-shaped relationship (e.g., Steenkamp and Gielens, 2003) hints at the possibility of a curvilinear association. As such, we reason that previous studies may be under-reporting the true nature of the firm-level product innovativeness-performance relationship. Critically, it is also unclear whether the relationship between firm-level product innovativeness and firm performance is 
weaker or stronger depending on organizational (e.g., access to resources) and/or environmental (e.g., competition) conditions (Droge et al., 2008; Hult et al., 2004). Examining this is important, since it is reasonable to assume that the existence and impact of such moderators may have a strong influence on ideal innovation strategies firms might wish to adopt given their resources and capabilities, and the external market conditions they face.

Likewise, it is not known whether firm-level product innovativeness outcomes vary across developed and emerging markets (Paunov, 2012). Differences exist in the level of institutional developments across such markets (Cavusgil et al., 2002; Bruton et al., 2010), which may have practical implications for those charged with managing firms' innovation strategies and for policy makers. If there is discrepancy in the way firm innovativeness shapes success across the two contexts, it might be attributable to institutional differences, and this may have knock on effects in terms of the resource requirements of firms and policies required to overcome institutional weaknesses (particularly in emerging markets, where institutional voids are common). Unsurprisingly, there are calls to investigate whether theories relating to innovation activities are universally applicable, and identify where their boundary conditions lie, across developed and emerging market contexts (Hoskisson et al., 2000). Thus, it is important to explore whether the main and moderated relationships between firms' product innovation activities and performance operate identically across developed and emerging market environments. Evidence on this front should help with the provision of clearer guidance to firms and governments with regards to innovation practice and policy.

Accordingly, in the current study, we examine firm-level product innovativeness, defined as the extent to which firms innovate intensely and the extent to which their product innovation portfolios are novel, and develop arguments to support the notion that an excessive focus on both intensive and novel innovation strategies can lead to diminishing returns. We also argue that firm-specific advantages (i.e., financial resources and market orientation) and firms' environment conditions (i.e., market dynamism) shape the consequences of firm-level innovativeness. Finally, we empirically compare the findings for our model based on data obtained for firms operating in the UK and in Ghana, so providing preliminary evidence on potential similarities and differences in the benefits and drawbacks accruing from firm-level innovation strategies in developed and emerging markets. 


\section{Theoretical Framework and Hypotheses}

\subsection{Firm-level Product Innovativeness}

Firm innovativeness is generally articulated as a continuum; with more innovative firms developing more really new, or radically innovative, products relative to their competitors (Damanpour, 1991). However, many authors highlight a lack of consistency in the definition and operationalization of innovativeness (e.g., Garcia and Calantone, 2002; Tajeddini et al., 2006; Wang and Ahmed, 2004), leading to problems in practice (Szymanski et al., 2007). The term innovativeness has also been applied at both a product level (e.g., Szymanski et al., 2007) and a firm level (e.g., Akgün et al., 2012; Wang and Ahmed, 2004). Garcia and Calantone (2002, p.113) define product innovativeness as "a measure of the potential discontinuity a product (process or service) can generate in the marketing and/or technological process..." and firm innovativeness as "the propensity for a firm to innovate or develop new products". While much extant research has studied product-level product innovativeness, there are also sound reasons for focusing on the firm-level.

First, decisions regarding how much is spent on generating and developing innovative capacities are taken at the firm level and many firms evaluate the ROI of R\&D activities at a broader firm-level (Özçelik and Taymaz, 2004). Thus, attempts to understand why a single product does well only allow a partial understanding of the ROI of R\&D activities. This becomes even more important as the number of innovation projects undertaken increases, since the explanatory power of a single project decreases (Damanpour, 1991). Second, given that innovation capabilities, as valuable and socially complex resources (Hult and Ketchen, 2001), affect firm-level competitiveness, focusing on the firm-level allows an understanding of how firms' capabilities differ and how these differences affect performance (Özçelik and Taymaz, 2004). Third, understanding how internal and external firm-level environmental and institutional factors affect performance requires a focus on firm-level activities; hence, our focus on firm-level product innovativeness.

An examination of the firm-level product innovativeness literature highlights further conceptual issues. In drawing on Hurley and Hult (1998), most authors conceptualize firm-level innovativeness as a cultural propensity to innovate (e.g., Calantone et al., 2003; Deshpandé and Farley, 2004; Kyrgidou and 
Spyropoulou, 2012; Wang and Ahmed, 2004). For example, Calantone et al., (2003, p. 93) define it as "the receptivity to new ideas and innovations as an integral part of a firm's culture [and] a measure of an organization's orientation towards innovation". However, in many of these definitions, there is a clear tension between innovativeness as a culture and innovativeness as a behavior. For example, Menguc and Auh (2006) argue that "firms that have high innovativeness, which is akin to an organizational culture that encourages employees to be innovative, are likely to have more innovation”. Calantone et al. (2002, p 517) conceptualize two innovativeness dimensions: a cultural perspective: "the organization's willingness to change"; and a behavioral standpoint: "the rate of adoption of innovations by the firm".

The notion that innovativeness is multi-dimensional is also well recognized (e.g., Garcia and Calantone, 2002), and while definitions highlight a number of innovativeness dimensions, including degree of newness (Danneels and Kleinschmidt, 2001) or radicality (e.g., Tellis et al., 2009), and intensity (e.g., Miller and Friesen, 1982; Tajeddini et al., 2006), most studies focus on the degree of newness. However, some studies also highlight the importance of examining new product numbers (e.g., Calantone et al., 2002; Damanpour, 1991; Tajeddini et al., 2006). Indeed, it has long been proposed that innovativeness should encompass firms' proclivity to embrace creativity, novelty and experimentation in new product development activities (Deshpandé and Farley, 2004), and their propensity to launch innovative new products intensively and relentlessly relative to competitors (Miller and Friesen, 1982; Tellis et al., 2009; Hua and Wemmerlov, 2006). While many definitions focus on 'newness'; the ‘intensity’ aspect is implicit (e.g., Calantone et al., 2002; Menguc and Auh, 2006). For example, Tajeddini et al., (2006, p 533) see innovativeness as "synonymous with the number of innovations, of any type", while Tellis et al. (2009, p 6, emphasis added) argue that "relentless innovation may help ensure that the firm stays constantly at the leading edge of innovation". Therefore, we define firm-level product innovativeness as a combination of the degree of novelty (newness) and intensity (number) of firms' new product offerings. Our rationale is that, in addition to requirements for a high degree of new product novelty in increasingly competitive markets, there is also the need for multiple new product offerings to satisfy diverse market demands. We contend that emphasizing novelty makes firms more competitive if they also offer novel new products more intensively, relative to industry rivals. This integrative view is in line with Milgrom and Roberts' (1994, p. 5) suggestion that "the gain from increasing every component 
[of a system] is more than the sum of gains from the individual increases", and is supported by the view that alignment of multiple strategic logics can boost performance (He and Wong, 2004).

\subsection{Firm-level product innovativeness in developed and emerging markets}

In our conceptual model, displayed in Figure 1, we explore the curvilinear relationship between firm-level product innovativeness and new product performance and examine the effect of a number of contingency factors. Beyond the expected contributions of firm innovativeness and the moderators examined to firms' new product performance, a key question is whether the relationships are identical or variant across developed and emerging markets, given differences in institutional environments (Deshpandé et al., 2013). Similarities might be expected because the institutions, while different, are only at different stages of development. Indeed, Arnold and Quelch (1998, p. 9) argue that emerging markets can be seen to be "at an early stage of the same development path followed by the advanced or developed countries... and that market evolution patterns seen previously in developed economies will be replicated in [emerging markets]". However, others argue that a firm's fate is tied closely to its unique institutional environment (Cavusgil et al., 2002; Bruton et al., 2010), thus, it is also reasonable to believe that variations might be seen across different institutional contexts (Hart and Christensen, 2002). In this study, we explore the relationships in two countries with varying institutional environments: the UK (a developed market) and Ghana (an emerging market).

Testing the model across developed and emerging market settings has the potential to yield preliminary and rich insights into the firm-level product innovativeness phenomenon. In developing arguments for potential similarities and differences in the model relationships across the UK and Ghana, we draw insights from institutional theory, building on the notion that firms could be both constrained and enabled by their institutional environments (van Waarden, 2001; Bruton et al., 2010). Institutional theory is concerned with the extent to which firms "secure their positions and legitimacy by conforming to the rules and norms of the institutional environment” (Bruton et al., 2010, p. 422). Institutions are made up of formal rules and regulations, and informal shared interactions and taken for granted assumptions that guide the behavior of individuals and organizations (Manolova et al., 2008). 
As a result, we build a model in which: (a) there are curvilinear and moderated relationships between firm-level product innovativeness and new product performance; and (b) the degree of institutional development across the UK and Ghana is identified as having the potential to determine how firm-level product innovativeness and new product performance are related. Of course, two-country comparisons provide only limited information given concerns over generalizing from two data points (Cadogan, 2010; Franke and Richey, 2010), and as a result, we stress that the tests of our arguments based on differences in institutions across the UK and Ghana are necessarily exploratory in nature. Nevertheless, our findings provide a rich platform from which to develop further our understanding of both the nature of the firm-level product innovativeness - new product performance relationship, and the role that nationlevel institutional factors may play in shaping that relationship. Each hypothesis is now developed below.

\section{Figure 1 here}

\section{3 Firm-level Product Innovativeness and Performance}

Significant innovations allow firms to renew their position in existing markets, enter new markets, and consider new market opportunities (Danneels and Kleinschmidt, 2001; Hult and Ketchen, 2001; Kyrgidou and Spyropoulou, 2012) because novel (or radical) new products enable firms to create a differentiation advantage over competitors (Tellis et al., 2009). Intensive introduction of innovative products enables firms to serve multiple and diverse market demands better than less intensive competitors (Hua and Wemmerlov, 2006). While much of the literature on firm-level innovativeness identifies a positive linear relationship with a wide range of performance outcomes (e.g., Tellis et al., 2009; Hult et al., 2004), many authors argue that knowledge still remains limited with regards to innovation efforts (e.g., Droge et al., 2008).

Furthermore, the literature on product-level innovativeness has long hinted that a curvilinear relationship should be expected (e.g., Steenkamp and Gielens, 2003); arguing that both low and high levels of product innovativeness are associated with superior performance as opposed to moderate levels. Guided by these arguments, it might also be reasonable to expect that under relatively low levels of firm-level innovation activity, increases in innovativeness may result in increased performance, but that beyond 
certain 'optimal' levels of innovativeness, further increases in firm-level product innovativeness might actually lead to decreases in performance.

Firstly, radical product innovation is a costly activity that can consume a substantial proportion of firm resources and overstretch overall product development budgets (Rosenbusch et al., 2011). Moreover, too much focus on developing highly innovative products could limit the range of opportunities open to firms (He and Wong, 2004). For example, too much emphasis on a strategy of developing very novel innovations can shift managers' attention away from a creative imitation, 'me-to' strategy, which has also been found to enhance customer value creation (Tellis et al., 2009). Furthermore, while radically innovative products may provide firms with greater returns, there is also the potential for higher risks and uncertainty, reduced synergy and decreased familiarity to customers, leading to reduced performance (Droge et al., 2008). Specifically, evidence shows that high levels of innovativeness are fraught with increased failure rates due to the high levels of risk and uncertainty involved (Montoya-Weiss and Calantone, 1994). The organizational literature also asserts that such failures can also disrupt existing operations (He and Wong, 2004). As Miller and Friesen (1982, p.6) state, “A proclivity towards [...] an innovation-embracing ideology can cause firms to squander resources in the pursuit of superfluous novelty".

Second, although the relentless introduction of innovative products provides firms with advantages, too much intensity might also be damaging. Specifically, firms innovating less often can still undertake targeted innovations, thus maximizing efficiency for greater margins, while keeping new product development costs down. In particular, Roberts (1999, p. 655) argues that "sustained high profitability may also accrue to firms that innovate less often", which implies that innovating relentlessly might not necessarily be beneficial for business success. Thus, we argue that the downward effect of too much novel and intensive product innovation activity has not been captured in the empirical literature, and requires further exploration.

While the high risks and uncertainties of innovation activities are likely to raise transaction and coordination costs for firms in both developed and emerging markets (van Waarden, 2001), institutions are expected to function to minimize these costs (Bruton et al., 2010), thus helping to increase success rates of innovation activities (van Waarden, 2001). Research shows that numerous country-level factors, including 
country culture, business environment, and infrastructure development, hold significant competitive advantage implications for local innovating firms (Deshpandé et al., 2013; de Soto, 2000). In the entrepreneurship domain, literature indicates that the success of entrepreneurial initiatives (such as new product introduction) can be directly affected by a country's laws, regulations, and innovation rewards allocation policies (Baumol et al., 2009), and that institutions can determine the scale and scope of innovation activities in an economy (de Soto, 2000). Thus, just as adequate institutional development is argued to support the performance outcomes of innovation activities (Baumol et al., 2009), inadequate institutional developments, as well as overly restrictive regulations are argued to hamper the success of innovation activities (de Soto, 2000).

However, in contrast, emerging market literature contends that, unlike developed market multinationals that preoccupy themselves with strategies to overcome institutional weaknesses in emerging markets, local emerging market firms tend to leverage the strengths of the existing institutional environment to their advantage (London and Hart, 2004). So, rather than allowing institutional voids to hold them back, emerging market firms aid their innovation efforts by developing social (not legal) contracts with non-traditional partners (e.g., local vendors and community leaders), co-innovating with local consumers and building local market knowledge capacity and in doing so reduce the risks and uncertainties associated with these innovation activities (Hart and Christensen, 2002). Thus, despite differences in levels of institutional development across the UK and Ghana, it can be said that firms in both markets leverage their home institutional conditions differently to their advantage. Furthermore, the earlier arguments made with regards to the potential negative effects of firms over-extending themselves with regards to developing too many novel innovations make it is reasonable to expect that, in the absence of moderating effects (see $\mathrm{H} 3$ and $\mathrm{H} 4$ ), firms in developed and emerging markets will derive similar benefits from innovation activities. Accordingly, we hypothesize that:

H1: Firm-level product innovativeness has an inverted U-shaped (negative quadratic) relationship with new product performance in both developed and emerging markets.

\subsection{Moderating effect of market orientation}


Firms that stay closer to customers and understand the activities of competitors by being marketoriented are likely to benefit more from innovation activity than those that do not emphasize these activities (Hult et al., 2004). Staying close to customers helps to generate and respond to intelligence on customers' present and future needs (Kohli and Jaworski, 1990), which helps firms to better target customer preferences with tailored innovative products. Because market-oriented firms monitor markets trends and tend to invest in understanding current and future customer needs better, they are more likely to develop products that benefit from greater product trials (Szymanski et al., 2007; Hult and Ketchen, 2001). A better understanding of competitors' activities and the wider competitive environment also enables firms to avoid innovating in product areas where competitors have greater advantage.

Although some research has explored the role of market orientation in the product innovativeness - performance link (e.g., Deshpandé and Farley, 2004; Hult et al., 2004; Menguc and Auh, 2006; Tajeddini et al., 2006), empirical evidence on how market orientation moderates the combined effects of product innovation novelty and intensity on performance is lacking. Hult et al. (2004) and Tajeddini et al. (2006) examine Narver and Slater's three dimensions of market orientation (Customer Orientation, Competitor Orientation and Inter-functional Coordination) as antecedents of innovativeness (defined as a business culture) and find that they are strongly correlated, and that innovativeness is strongly correlated with business performance, but do not empirically examine innovativeness from a behavioral perspective or from a novelty and intensity perspective. Menguc and Auh (2006) examine the interaction effect of levels of innovativeness on the market orientation-performance relationship. However, Lado and MaydeuOlivares (2001, p. 130) posit that "the magnitude and the effectiveness of the innovation activities of a firm can be enhanced through the adoption of market orientation principles" and Deshpande and Farley (2004) argue for a focus on market orientation as a moderating variable in studies of firm performance. Thus, we focus on market orientation as a moderator of the product innovativeness-performance relationship. Furthermore, we argue that as firms develop greater intelligence about the market and where success is most likely to come from, they are more likely to focus on innovations that will succeed in the marketplace, enabling firms to create better market offerings than their market intelligence deficient counterparts. 
Considering the moderating effect of market orientation specifically in the UK and Ghana contexts, the overwhelming evidence based on the practices of developed market companies is that high levels of market orientation is associated with greater new product success (Kirca et al., 2005; Cano et al., 2004). Underlying this finding is the idea that the economic and institutional environment in developed economies is supportive of capitalist focused market-based behaviors (Baumol et al., 2009). Indeed, the central role of the marketing concept and its customer-centric perspective of new product development are well rooted in developed market economies. However, a few emerging market studies have also reported similar findings (Atuahene-Gima et al., 2005; Boso et al., 2012) and other studies point to similarities with regards to the moderating effect of market orientation in the sense that while developed market firms often rely on traditional market research tools to gain greater understanding of customers and learn about competitor activities and the wider macro environment, emerging market firms simply use different strategies to gather and utilize market intelligence to aid innovation efforts (Ingenbleek et al., 2013). Thus, as previous research findings indicate, there is a basis to expect a similar moderating effect of market orientation across both market settings. Accordingly, we argue that:

H2: In firms with greater market orientation levels, the negative quadratic relationship between firm-level product innovativeness and new product performance is less negative relative to firms with lower market orientation levels, in both developed and emerging markets.

\subsection{Moderating effect of access to financial resources}

Given that innovation is a costly activity and requires financial resources, and in view of the fact that firms vary in their cost structure and in the amount of financial resources devoted to new product development (Tellis et al., 2009), we expect access to financial resources to be an important moderator of the firm-level product innovativeness - performance relationship. While some literature argues that greater financial constraint may be a major determinant of product innovation success (Hoegl et al., 2008), it is well recognized that greater access to financial resources supports product innovation success (Damanpour, 1991). The reasoning is that more financial resources are required to fund "such activities as experimenting, idea generation and selection, customer surveys, collaboration with suppliers and technology partners, and prototype testing” (Hoegl et al., 2008, p. 1383). Thus, firms with greater access to 
financial resources are able to leverage their innovation investments more effectively than less wellresourced firms, because these financial resources ensure that necessary follow-up supply, production capacity and marketing-related costs can be met. They also allow firms to invest in personnel, so that the added managerial complexity, brought about by having more complex and diverse new product portfolios, can be handled without losing focus. As such, variations in access to financial capital are expected to lead to differences in performance outcomes.

As far as the moderating effect of access to financial capital is concerned, it seems reasonable to expect that there may be differences between the UK and Ghana. First, research into the cost of innovating suggests that emerging markets (relative to developed markets) are low cost locations for R\&D operations (a proxy for firm innovation) (Gao et al., 2007). For example, Reddy (1997) argues that a primary reason for increased strategic R\&D operations of multinational enterprises in emerging market countries is the potential to exploit cost differentials. R\&D activities (including developing new capacity, hiring new personnel, sourcing materials, and complying with industry regulations) are cheaper in emerging markets relative to developed markets (Eweje, 2009; Reddy and Sigurdson, 1997), in which case, it is possible that the marginal benefits accruing to firms with excess financial resources in Ghana will be greater than recipients of financial resources in the UK, as firms in Ghana (relative to those in the UK) are likely to enjoy the benefit of lower cost structures (Chatterjee, 1990). Furthermore, it can be argued that greater financial resources will be more beneficial in supporting innovation activities in emerging economies when one considers the lack of market-based institutions that protect intellectual property in these economies, which increase the costs and risks of doing business in these countries (Manolova et al., 2008). Financial resources might also be supportive in enabling firms to deal with typically elongated and bureaucratic procedures that often discourage firms from investing in new product activities in emerging markets (de Soto, 2000). Accordingly, we hypothesize that:

H3a: In firms with greater access to financial resources, the negative quadratic relationship between firmlevel product innovativeness and new product performance is less negative relative to firms with less access to financial resources. 
H3b: When access to financial resources is stronger, the negative quadratic relationship between firmlevel product innovativeness and new product performance should be more negative in the UK and less negative in Ghana.

\subsection{Moderating effects of environment dynamism}

Environments that are characterized by frequent changes in customer needs and preferences and unpredictable competitive strategies are often classified as dynamic (Jaworski and Kohli, 1993). The literature tends to partition the environment into customer, competitor and technology dimensions (Jaworski and Kohli, 1993). However, in view of the fact that the impact of technological turbulence on innovation success is widely known, for conceptual clarify, we only focus on customer and competitor dynamism (Joshi and Campbell, 2003).

Research shows that increased environment dynamism is the strongest determinant of market uncertainty (Jaworski and Kohli, 1993). To succeed in such environment conditions, firms need to be more innovative to meet evolving customer needs and wants, and to avoid competing in territories where competitors have greater strengths (e.g., Droge et al., 2008). Miller and Friesen (1982) argue that firms should be more innovative in dynamic environments because such environments are characterized by the increased introduction of competitive new products and greater fluctuations in customer needs and preferences. Thus, while novel product innovations can involve higher order learning and greater risk for customers, when the environment is in a state of flux they can generate high product trials, support customer variety-seeking tendencies and lead to repeat purchases (Szymanski et al. 2007).

Similarly, the impact of product innovation intensity on performance might be moderated by environment dynamism because firms need lots of new products to satisfy diversities in customers' needs and preferences, and to ensure that the firm does not lose ground to the changing strategies of competitors (Joshi and Campbell, 2003). In contrast, firms faced with stable markets have a less pressing need to innovate (Droge et al., 2008). Thus, it is likely that the drawbacks of innovation activity are likely to be accrued at lower levels of investment in innovation activity, reducing the 'optimal' level of innovativeness. Hence, we posit that greater firm innovativeness will be more successful in more dynamic market environments than in more stable environments. 
Again, we argue that we may find differences in the moderating effect of market dynamism across the UK and Ghana. Although highly intense competition and large shifts in consumer preferences provide conditions where greater innovativeness should be more beneficial for firms (Jaworski and Kohli, 1993), such shifts also bring with them the need for the firm to be flexible and agile in order to accommodate the organizational changes that dynamism necessitates (e.g., to the marketing organization, technology, administration, see Greenley, 1995). We argue that the ability to adapt in an agile manner may be reduced in Ghana, relative to the UK, because of the higher levels of government regulation and bureaucracy and the fact that critical institutions are still in transition, making change more cumbersome.

Related to this is the idea of whether emerging market firms (relative to developed market counterparts) are able to create required structural changes to be effective in dynamic environments when faced with institutional voids. For example, Hart and Christensen (2002) argue that firms in emerging markets often lack the skills and capabilities required to compete as effectively in a rapidly evolving market environments. Thus, we take the view that the need to redesign marketing operations, administrative functions, and implement new technologies as a result of innovating in dynamic markets may overstress emerging market firms' capabilities and add a disproportionate burden on the firm's coordination outlays, reducing the effectiveness of their innovation activities overall, relative to developed market firms. Accordingly, we hypothesize that:

H4a: In firms operating in more dynamic markets, the negative quadratic relationship between firm-level product innovativeness and new product performance is less negative relative to firms operating in more stable markets.

H4b: When market environment conditions are more dynamic, the negative quadratic relationship between firm-level product innovativeness and new product performance is less negative in the UK and more negative in Ghana.

\section{Methodology}

\subsection{Settings and Instrument Design}

Data for this study were collected from the United Kingdom (UK), an advanced Western market, and Ghana, an emerging Sub-Saharan African market (Hoskisson et al., 2000). For both studies a structured 
questionnaire was used to measure the constructs of interest.

\subsection{Data Collection}

We targeted a sample of local firms in each country; thus, firms that were subsidiaries of foreign parent companies were not involved in the current study. In other words, we sample only independent firms, as the strategy of subsidiaries may be influenced by corporate headquarters (Wiklund and Shepherd, 2011). Because each country offered specific opportunities and limitations, the actual data collection procedures followed varied slightly across each location. In both settings, Chief Executive Officers (CEOs) and Finance Managers were contacted for information. The use of a multiple informant research design helped to minimize concerns about common method bias (Podsakoff et al., 2003). We assessed the competence of the informants in both locations on three key areas: (1) knowledge about the questions asked; (2) accuracy of the answers provided; and (3) confidence in the answers provided. The informant competence measures were assessed on a seven-point Likert scale $(1=$ strongly disagree; $7=$ strongly agree). As Table 1 indicates the minimum score of 6.37 implies that the informants were highly knowledgeable on the issues under examination and had strong confidence in the accuracy of the answers provided.

The United Kingdom (UK) Study: A multi-industry UK survey was undertaken using the FAME ${ }^{1}$ database as a sampling frame (Wang, 2008). The FAME database contains up to date information on UK and Irish companies and has listings for over seven million companies. In the first-wave survey (T1), a random sample of 1,500 firms with operations in the UK was contacted with a questionnaire by mail. After two reminders, 324 responses were received from the CEOs and after discounting questionnaires with extreme missing values, 319 useable responses were obtained, an effective response rate of $21.3 \%$. One year later (T2), Finance Managers for the same sample of firms were contacted by mail with a separate questionnaire focusing only on performance measures. We obtained 223 matched pairs of responses. Given the lower responses from the Finance Managers, we followed established tradition (e.g., Van Bruggen et al., 2002) to compute the interrater agreement index $\left(\mathrm{r}_{W G}\right)$ for each of the performance measures from the two informant groups. The lowest $r_{W G}$ index for the entire set of items was .81 , which is

\footnotetext{
${ }^{1}$ The FAME database is a directory of companies listed by industry sector and contains information on companies active in a particular industry. The database is accessible via http://fame.bvdep.com.
} 
well above the recommended .70 benchmark (Van Bruggen et al., 2002), and showed a high level of agreement between the two informant groups on the new product performance indicators.

Given these encouraging results, we aggregated responses from the two informant groups to obtain a single group composite value for the new product performance items (Van Bruggen et al., 2002), and the combined data was used in further analysis (De Luca and Atuahene-Gima, 2007). As can be seen in Table 1, the average business experience of the firms is 49.21 years. The firms have an average of 10,872 fulltime employees and a mean total annual turnover of over US\$ 78.42 Million. The specific industries the firms operate in include: financial services (27\%); transport (20\%); construction (17\%); electronics and industrial machinery (11\%); computers and computer accessories (5\%); defense equipment (5\%); automobiles (including accessories) (4\%); hospitality (4\%); healthcare (3\%); wholesale and retail services (3\%); and textiles (1\%). Overall, $74 \%$ of the firms operate in services sector while the remaining $26 \%$ are manufacturers of physical goods.

The Ghana study: The study involved a multi-industry study of companies with operations in Ghana. The sampling population contained 6,456 incorporated firms obtained from the Ghana's company register database (available at Registrar General's Department), and the Ghana Business Directory (Acquaah, 2007). From the combined list, we randomly selected 789 independent companies that met our specified criteria ${ }^{2}$. In the first-wave survey (T1), 312 CEOs representing each company agreed to participate in the study and were each handed a questionnaire in person. One year later (T2), Finance Managers from the same firms were contacted in person with another questionnaire to capture performance measures. Complete and matched responses were received from 221 firms (70.9\%) with .95 as the lowest $\mathrm{r}_{W G}$ index for the entire set of items. As seen in Table 1, on average, the firms have been in business for 28 years, have 15 full-time employees and the average annual turnover is US\$ 300,200. 73\% are manufacturers of physical goods and $27 \%$ are service providers. Specific industries include agroprocessors (32\%), textiles and garments (21\%), financial services (15\%), crafts \& artisans (10\%), transport operators $(6 \%)$, incorporated restaurants and bars (4\%), wholesale and retail (2\%), beverages (5\%), flour

\footnotetext{
${ }^{2}$ We focused only on: (1) firms that were independent entities and not part of any company group or chain (Wiklund and Shepherd, 2011); (2) firms that employed a minimum of five and a maximum of 500 full-time staff (Wiklund \& Shepherd, 2011); (3) manufacturers of physical products or service providers that engaged in productive business activities (Morgan et al., 2004); (4) firms that had a minimum of five years of business operation (Morgan et al., 2004), and (5) firms that had complete contact information on the Chief Executive Officer or an officer at senior management level.
} 
millers (3\%), and mining and quarrying (2\%).

\section{Table 1 about here}

\subsection{Measures}

Consistent with the literature, multi-item measures with seven-point items were used to measure all constructs. The novel product innovativeness scale relates to the degree to which a firm's new products are radical, creative and inventive relative to competitors' new products and is measured with three items adapted from existing scales (e.g., Tellis et al., 2009; Wang and Ahmed, 2004). The intensive product innovativeness scale describes the number of new products a firm introduced to its target markets relative to its competitors' product innovation activity and is measured using three items based on previous scales (e.g., Wang and Ahmed, 2004;). Following past research that has adopted a unifying approach to innovation (e.g., Lubatkin et al., 2006) we combined these to create a single measure of firm-level product innovativeness (PI).

We follow Jaworski and Kohli's (1993) behavioral conceptualization of market orientation (MO) and measure three dimensions of: market intelligence generation, market intelligence dissemination and market intelligence responsiveness. We operationalize these dimensions using specific items from Cadogan et al. (1999), as their cross-national validity and reliability have been confirmed in several empirical studies (e.g., Cadogan et al., 1999; Cadogan et al., 2001). Market intelligence generation and market intelligence dissemination are both measured with four items whereas market intelligence responsiveness is measured with three items.

In line with the arguments of Howell et al. (2007), we treat firm-level product innovativeness and market orientation as formative indices because their component first-order factors are conceptualized as distinct but correlated constructs that define the focal constructs. Hence, in operationalizing firm-level product innovativeness, we obtained a single score for intensive product innovativeness (INT) by averaging across its three scale items. We followed a similar procedure to obtain a single score for novel product innovativeness (NOV). To calculate a score for firm-level product innovativeness (PI), we added the INT and NOV scores and divided the resulting score by two. Similarly, for market orientation (MO), we first created single scores for the three dimensions: generation (GEN), dissemination (DIS) and 
responsiveness (RESP) by averaging across their respective scale items, and then average across the three factors to obtain an MO score.

Our financial resource (FIN) measures, adopted from Wiklund and Shepherd (2005), assess managers' levels of satisfaction with access to financial capital, measured using four items. In line with Dess and Beard (1984) and Miller and Friesen (1982), we assess market environment dynamism (DYN) by using three items that tap managerial perceptions of the degree of variation in the target market environment. The new product performance (NPP) measure is based on Atuahene-Gima et al.'s (2005) 'new product success' scale, which uses four items to assess revenue from new products or services, and growth in revenue, sales and profitability of new products or services during the previous three years.

We also control for several variables: firm size, measured by logarithm transformation of number of employees; R\&D spend, assessed by logarithm transformation of annual total R\&D expenses; industry dummy ( 1 = physical goods versus $1=$ services $)$; and business experience, measured by logarithm transformation of number of years a firm has been in business. Details of measures used are provided in the Appendix.

\section{Analyses}

\subsection{Reliability and Validity Assessment}

To evaluate the reliability and validity of each construct for both the UK and Ghanaian samples, we first ran exploratory factor analyses (EFA) for each sample, and then further refined the items in confirmatory factor analyses (CFA) using LISREL 8.5 and covariance matrices as input data. The final CFA results show a good fit to the data. For the UK sample, we obtained a satisfactory model fit: $\chi^{2}$ (d.f.) $=$ 830.14 (479); $\mathrm{p}$ <.00; Root Mean Square Error of Approximation (RMSEA) = .05; Non-Normed Ft Index $(\mathrm{NNFI})=.92$; and Comparative Fit Index $(\mathrm{CFI})=.93$. Similar acceptable results were obtained for the Ghanaian sample: $\chi^{2}$ (d.f.) $=528.31(479) ; \mathrm{p}<.00 ;$ RMSEA $=.02 ; \mathrm{NNFI}=.97$; and CFI $=0.97$. Factor loadings for each construct are significant at $1 \%$ for both samples which therefore support convergent validity of the measures (Bagozzi and Yi, 1988). Given that coefficient alpha is suggested to understate reliability (Fornell and Larcker, 1981), we assessed reliability by using three indicators of convergent and discriminant validity: composite reliability (CR), average variance extracted (AVE), and highest shared 
variance (HSV) (Hansen et al., 2011). As can be seen in Appendix, construct reliability assessment for each construct for both samples generate indices that are far larger than the recommended .70 cutoff (Bagozzi and Yi, 1988). Using Fornell and Larcker's (1981) procedure, we assess discriminant validity of each construct by examining whether or not the AVE for each construct was larger than the shared variances (i.e., squared correlations) of each pair of construct. Results show that discriminant validity is demonstrated for each construct for both samples, as the AVE for each construct is greater than the HSV between each pair of constructs. Correlations between constructs are provided in Table 2.

\section{Table 2 about here}

\subsection{Common Method Variance Assessment}

Although we obtained information on the variables from multiple sources, which effectively minimizes common method variance (CMV) problems, for each country, several tests were performed to ensure that CMV was not a major problem in our data. First, Lindell and Whitney's (2001) test for CMV was administered: a marked item was identified, one that is not conceptually associated with any construct in the model tested. On this front, a measure of competitive aggressiveness was identified as a variable that is not conceptually associated with any construct in the model (i.e., "We typically adopt an undo-thecompetitor posture in our target markets"). The correlation between this item and all study constructs was calculated, and results show low non-significant correlations, ranging between -.00 and .11(see Table 2), indicating that CMV effects do not substantially account for the relationships between the constructs studied. Second, a Harman's one-factor test in CFA returned a poor model fit for the UK sample: $\chi^{2}$ (d.f.) $=$ 3572.35 (524); $\mathrm{p}<0.001 ; \mathrm{RMSEA}=0.16 ; \mathrm{NNFI}=0.26$; $\mathrm{CFI}=0.30$, and for the Ghana sample: $\chi^{2}(\mathrm{~d} . \mathrm{f})=$. $4464.29(527) ; \mathrm{p}<0.001 ; \mathrm{RMSEA}=0.18 ; \mathrm{NNFI}=0.17 ; \mathrm{CFI}=0.19$. This indicates that a bias factor is most unlikely to explain the variances in the measures.

\subsection{Measurement Invariance Assessment}

Having assessed the reliability of each construct for both samples, we then evaluated the measurement invariance of the measures. Measurement invariance (or equivalence) refers to "whether or not, under different conditions of observing and studying phenomena, measurement operations yield 
measures of the same attribute" (Horn and McArdle, 1992, p.117). In line with this understanding, we tested for configural (i.e., the items comprising the measures demonstrate the same pattern of factor loadings), metric (i.e., evidence of equal loadings), scalar (i.e., equivalence of intercepts), factor variance (i.e., equality of factor variances) and error variance (i.e., equal measurement error) invariance for each construct (Steenkamp and Baumgartner, 1998). We assessed fit of the models using chi-square difference tests and four approximate fit indices: RMSEA, NNFI, CFI and Consistent Akaike Information Criterion (CAIC) (Horn and McArdle, 1992; Steenkamp and Baumgartner, 1998). Because several invariance tests were undertaken (eight in total), we illustrate the procedure used with the test of firm-level product innovation intensity measures (i.e., a single-factor CFA model with three items).

In the first step, we estimated a two-group CFA model as a baseline model without imposing any multi-group constraint (except for a single loading that was constrained to be equal to 1). As can be seen in Table 3, because the configural model was a single-factor model with no degrees of freedom an optimal model fit was obtained: $\chi^{2}$ (d.f.) $=.00(0) ; \mathrm{p}$-value $=1.00 ; \mathrm{RMSEA}=.00 ; \mathrm{NNFI}=1.00 ;$ and $\mathrm{CFI}=1.00$. All factor loadings were significant at $1 \%$ across both countries, and so we conclude that the scale exhibits configural invariance across the two countries. The second step was to constrain the matrix of factor loadings to be equal. The metric invariance model exhibited a satisfactory fit to the data: $\chi^{2}($ d.f. $)=.64$ (2); $\mathrm{p}$-value $=.73 ; \mathrm{RMSEA}=.00 ; \mathrm{NNFI}=1.00 ; \mathrm{CFI}=1.00 ;$ and $\mathrm{CAIC}=117.30$. Moreover, the nonsignificant difference in chi-square between the metric and the configural models indicates that the factor loadings were invariant $\left(\Delta \chi^{2}(2)=.64 ; p>.05\right)$. Third, we tested for scalar invariance by further constraining item intercepts to be invariant, and obtained a good fit with the data: $\chi^{2}($ d.f. $)=2.38(5)$; pvalue $=.79 ; \mathrm{RMSEA}=.01 ; \mathrm{NNFI}=1.00 ; \mathrm{CFI}=1.00 ;$ and $\mathrm{CAIC}=97.17$. The non-significant difference between the scalar and the metric models supports scalar invariance $\left(\Delta \chi_{(3)}^{2}=1.74 ; \mathrm{p}>.05\right)$. Fourth, we tested for factor invariance by constraining the factor variance equal across both countries, and obtained satisfactory fit with the data: $\chi^{2}$ (d.f.) $=2.41(6) ; \mathrm{p}$-value $=.88 ; \mathrm{RMSEA}=.01 ; \mathrm{NNFI}=1.00 ; \mathrm{CFI}=1.00$; and $\mathrm{CAIC}=89.90$. We also obtained a non-significant chi-square difference between the factor invariance and the scalar models $\left(\Delta \chi_{(1)}^{2}=.03 ; p>.05\right)$, providing support for factor invariance. Finally, we tested for error invariance by further constraining item error variances to be invariant, and obtained a good fit to the data: $\chi^{2}$ (d.f. $)=3.32(9) ;$-value $=.95 ;$ RMSEA $=.01 ; \mathrm{NNFI}=1.00 ; \mathrm{CFI}=1.00 ;$ and $\mathrm{CAIC}=68.95$. In 
addition, we find a non-significant chi-square difference between the error invariance and factor invariance models $\left(\Delta \chi_{(3)}^{2}=.91 ; p>.05\right)$, supporting error invariance across both groups. Thus, as Panel A and Panel $\mathrm{B}$ in Table 3 report, the results show that configural, metric, scalar, factor variance, and error variance invariances exist for all items across the UK and Ghanaian samples, the items are equally reliable across the samples, and as such, the measures can be used for hypothesis testing.

\section{Table 3 about here}

\section{Results}

\subsection{Structural Model Estimation}

Because the study provides support for high levels of measurement invariance for the model constructs across the two samples, we can further estimate and compare the structural relationships between variables for both the UK and Ghanaian firms. Accordingly, we followed the traditional multiplicative and quadratic approaches to test the hypotheses by using maximum likelihood estimation method implemented in LISREL 8.5 (Ping, 1995). To analyze the structural equations, we first created single indicants for each construct involved in the quadratic and multiplicative interactions to reduce model complexity (e.g., Ping, 1995). Because our structural model includes multiple quadratic and multiplicative interactive terms, we attenuate for potential multicollinearity difficulty by residual-centering all measures using the procedure recommended by Little et al. (2006). Subsequently, we estimated and compared nine multi-group models to test the hypotheses (see Table 4).

In Model 1, which was the baseline model, the control variables were freely estimated and were forced to be invariant across both samples, but the hypothesized paths were set to take on the value of zero. Model 1 fits the data well: $\chi^{2}$ (d.f.) $=123.99(81) ; \mathrm{p}<.01 ; \mathrm{RMSEA}=.04 ; \mathrm{NNFI}=.96$; and $\mathrm{CFI}=$ .99. In Model 2, the estimated control paths were allowed to vary across the samples, but the hypothesized paths were restricted to take on zero, and relative to Model 1 a better fit was obtained for Model 2: $\left(\Delta \chi^{2}(11)\right.$ $=38.40 ; \mathrm{p}<.01)$. In Model 3, all the hypothesized paths were allowed to take on non-zero values, but were set invariant across both countries and with all remaining paths also set invariant across both samples. Model 3 is worse and is not significantly different from Model $2\left(\Delta \chi^{2}(7)=5.26 ; p>.05\right)$. Model 4 was then estimated with all hypothesized paths allowed to take on non-zero values, forced to vary freely 
across both countries, but with all remaining paths set invariant across both countries (Song et al., 2005).

Findings indicate a significant drop in chi-square $\left(\Delta \chi^{2}{ }_{(3)}=8.5 ; \mathrm{p}<.05\right)$ relative to Model 2.

We also performed additional tests (i.e. Model 5 to Model 9) to identify specific paths that differed across both countries (Song et al., 2005). Specifically, in Model 5, we re-estimated Model 4 but constrained PI-squared invariant across both countries, however, no significant chi-square change was obtained $\left(\Delta \chi_{(1)}^{2}=1.01 ; p>.05\right)$. The difference in chi-square was non-significant in Model $6\left(\Delta \chi_{(1)}^{2}=\right.$ 1.09; $\mathrm{p}>.05$ ) when Model 4 was re-estimated with PI-squared x MO constrained invariant across both samples. We obtained significant chi-square differences in Model $7\left(\Delta \chi^{2}{ }_{(1)}=10.38 ; \mathrm{p}<.05\right)$ and Model 8 $\left(\Delta \chi_{(1)}^{2}=10.98 ; \mathrm{p}<.05\right)$ when we respectively constrained PI-square $\mathrm{x}$ FIN and PI-square $\mathrm{x}$ DYN invariant across both countries. Finally, in Model 9 we re-estimated Model 4 and further constrained both PI-squared and PI-square x MO invariant across both countries. Here, a non-significant change in chisquare was obtained $\left(\Delta \chi^{2}{ }_{(2)}=3.40 ; \mathrm{p}>.05\right)$ together with a marginal $1 \%$ increase in $\mathrm{R}^{2}$ for the UK sample (see Table 4). Accordingly, we rely on Model 9 to interpret the hypotheses.

To explore the curvilinear effect further, we estimated quadratic terms and plotted the quadratic curves in Figure 2 for each country. Inspired by Aiken and West (1991), we decomposed the interactions, to probe the moderating effects fully. Specifically, we compared the innovativeness - performance relationship at low and high levels of the interaction variables, with low levels set at one standard deviation below the means and high levels fixed at one standard deviation above the means. We then performed simple slope tests and plotted the interactions in Figure 3.

\subsection{Direct effects}

Table 5 reports the estimated structural paths and their respective T-values. Hypothesis 1 predicts that firm-level product innovativeness has an inverted U-shaped relationship with performance in both the UK and Ghana. The linear term of innovativeness relates positively with performance for both UK and Ghanaian $(\gamma=.27 ; \mathrm{t}=6.11)$ firms, while the squared term of product innovativeness relates negatively with performance in both UK and Ghanaian $(\gamma=-.24 ; \mathrm{t}=-4.25)$ samples. Hence, hypothesis 1 is supported in both samples. Figure 2 further illustrates these effects of product innovativeness (i.e., the total effects of PI and PI-squared). As Figure 2 shows, firms in both UK and Ghanaian markets face a decline in 
the positive effect of innovativeness after a certain level, further indicating support for hypothesis 1 . Looking at Table 4 (Model 9), evidence shows that the effect of firm-level innovativeness on new product performance is not significantly different across both contexts.

Table 4 and Table 5 about here

Figures 2 and 3 about here

\subsection{Moderating effects}

Hypothesis 2 posits that market orientation moderates the curvilinear relationship between firmlevel product innovativeness and new product performance. We find that the PI-squared and market orientation interaction term is positive and significant for both UK and Ghanaian $(\gamma=.22 ; \mathrm{t}=4.63)$ firms, in support of hypothesis 2. From Figure 3A, it is clear that the negative quadratic relationship between innovativeness and performance becomes less negative as market orientation levels increase in both market settings, the relationship eventually becomes U-shaped at high market orientation levels.

In hypothesis $3 \mathrm{a}$, we propose that the negative quadratic relationship between firm-level product innovativeness and new product performance is less negative for firms with stronger access to financial resources, and in hypothesis $3 \mathrm{~b}$, we argue that this relationship should vary across the UK and Ghanaian market contexts. Looking at Table 5, we can see that there is no support for hypothesis $3 \mathrm{a}$ in the UK sample as the interaction term (i.e., PI-squared $\mathrm{x}$ financial resource) is non-significant $(\gamma=.10, \mathrm{t}=1.38)-$ see also part 1 of Figure 3B. However, hypothesis 3a is supported in the Ghanaian sample because the interaction term is positive and significant $(\gamma=.16 ; \mathrm{t}=1.69)$. As we show in part 2 of Figure $3 \mathrm{~B}$, at low levels of access to financial resources, there is a negative quadratic (inverted $U$-shaped) relationship between innovativeness and performance; however, at higher levels of access to financial resources, the relationship between innovativeness and performance becomes U-shaped for the Ghanaian firms. In support of hypothesis $3 b$, the moderating role of financial resources is much more obvious (i.e., stronger) in Ghana relative to the UK.

Hypotheses 4a argues that market environment dynamism moderates the curvilinear relationship between firm-level product innovativeness and new product performance, and hypothesis $4 \mathrm{~b}$ posits that the moderating effect relationship is different across the UK and the Ghanaian contexts. For the UK sample, 
the interaction term involving PI-squared and dynamism is positive and significant $(\gamma=.12 ; \mathrm{t}=2.65)$, providing support for hypothesis $4 \mathrm{a}$. However, the interaction term for the Ghanaian sample is negative and significant $(\gamma=-.15 ; \mathrm{t}=-2.17)$, indicating a lack of support for hypothesis $4 \mathrm{a}$ in the Ghana sample. As can be seen in part 1 of Figure 3C, for the UK sample the negative quadratic relationship between product innovativeness and new product performance is less negative under high environmental dynamism. The opposite is true for the Ghanaian sample (see part 2 of Figure 3C), where the invert U-shaped relationship becomes more pronounced (i.e., more negative) as environmental dynamism increases. Again, the finding of differences across the UK and Ghana of the moderating role of market environment dynamism broadly supports hypothesis $4 \mathrm{~b}$.

\subsection{Robustness Check}

Finally, we test whether the relationships examined work differently for specific informants (i.e., CEOs versus Finance Managers). For each country we run two additional full structural models: one with performance data provided by CEOs; and a second with performance data from Finance Managers. We find that the parameter estimates reported above remain unchanged for both data sources. These findings reinforce the strong interrater agreement index between the two performance data sources reported and further support the robustness of the models developed. In addition, the causal paths reported in Table 5 were tested on self-reported objective new product performance data (i.e., finance managers were asked to indicate new product sales within the immediate past three years). Results remained qualitatively unchanged with exception of the quadratic-interaction term involving product innovativeness and environment dynamism for the UK sample, which became less significant $(\gamma=.11 ; \mathrm{t}=1.91 ; \mathrm{p}<.05)$ but stayed positive and significant.

\section{Discussion}

\subsection{Theoretical contributions}

Past research affirms that firm innovativeness matters for firm success (e.g., Tellis et al., 2009). However, conflict in these findings raises the question of how, specifically, firm-level product innovativeness contributes to firm success (Rosenbusch et al., 2011). Further, the product innovation literature continues to debate the issue of whether findings obtained in developed market settings transfer 
to less developed market contexts, given that the institutional environments in developed markets are strikingly different from conditions in less developed markets (Acquaah, 2007). Our study expands existing literature by examining a more complex model where the firm-level product innovativeness performance relationship is curvilinear, and is dependent on organizational and external task environment factors. We test our conceptual model on firms operating in the UK and in Ghana, providing an opportunity to investigate our model across developed and emerging market contexts. Accordingly, this study makes several theoretical contributions.

First, our findings indicate that the relationship between firm-level product innovativeness and new product success is curvilinear, and this relationship form is evident in both developed and emerging market settings. Thus, our findings suggest that the product innovativeness-performance relationship is more complex than previously postulated, and that firm-level product innovativeness is not always beneficial for business success (Rosenbusch et al., 2011; Roberts, 1999). We believe that this finding helps expand our understanding of the beneficial consequences of product innovativeness beyond linear assessments and industrialized market practices by showing that, in many situations, increasing levels of product innovativeness eventually generate diminishing returns for firms operating in both developed and emerging markets. A key lesson from this finding may be that the institutional environment a firm operates in might not always make a difference in terms of the benefits that firms gain from innovation activities. Thus, as London and Hart (2004) suggest, firms may be able to leverage the institutional environment in home markets to their economic advantage. Perhaps this preliminary evidence may explain the recent surge in the introduction of innovative new products from emerging markets to the global marketplace, which suggests that emerging market firms have leveraged institutional condition at home to innovate successfully to compete against developed market counterparts (Hart, 2010).

Second, our findings also add to research on organizational innovation (e.g., Akgün et al., 2012) by suggesting that the beneficial effect of firm-level product innovativeness depends on levels of market orientation in the firm, and with important implications for firms in both developed and emerging markets. Greater market orientation helps firms to generate superior performance benefits from increased innovativeness (e.g., Lado and Maydeu-Olivares, 2001). For firms innovating in both markets, market orientation enables firms to better target innovative new products to customer needs and preferences and 
open up new and under-served market niches, which facilitates the success of innovative new product offers. Given differences in institutional environments, a major lesson from this finding may be that firms in both developed and emerging markets utilize their home institutional environment differently to their advantage. Drawing on the work of Arnold and Quelch (1998), we argue that, whereas in developed markets firms might rely on partner selection policy that emphasizes clearly defined and legally binding sets of functions (e.g., product warehousing, wholesaling, and retailing) due to well-developed legal systems and advanced distribution infrastructure, in emerging markets where firms are mindful of weak law enforcement and infrastructural deficiency, they are more likely to rely more on informal social (not legal) contracts and non-traditional distribution channels (e.g., local vendors, and known leaders of local community groups) to not only distribute new products but also gather local market intelligence (see also Ingenbleek et al., 2013) for targeted market selection, and positioning and efficient distribution of new products. Thus, while market orientation is important in both markets, the mechanisms utilized may differ.

Third, our findings on the moderating effects of access to financial resources and environment dynamism vary across developed and emerging markets. In Ghana, we find that greater access to financial resource positively facilitates the benefits of firm innovativeness, supporting the long-held proposition that more finances are needed for greater innovation success (Damanpour, 1991). This is unlike the UK, where greater access to financial resources has no significant impact on the firm innovativeness-performance relationship. One possible reason for this finding may be differences in the costs of innovating in developed versus emerging markets, related to the different relative costs of R\&D operations (Reddy, 1997; Reddy and Sigurdson, 1997). Thus, we think that in view of the lower cost of innovating in emerging markets (relative to developed markets), the marginal benefits accruing to Ghanaian firms with greater access to financial resources would be greater than UK firms with similar access to financial resources (Chatterjee, 1990). Relative to UK firms, companies in Ghana may have lower cost structures when it comes to innovating and this may have a knock on effect on their financial performance. In addition, unlike developed markets, emerging markets often suffer from greater political instability, corruption, and uncertain macro-economic conditions (Goedhuys and Sleuwaegen, 2010), which may increase risks and uncertainties (Hoskisson et al., 2000) associated with innovation activities. The literature suggests that while some emerging market firms are good at taking advantage of institutional 
limitations at home, others perceive institutional voids as weaknesses that must be avoided (Arnold and Quelch, 1998). Potentially, emerging market firms with more financial resources might outperform competitors with financial resource constraints because they are able to utilize these resources to create ways to overcome institutional voids, for example, by developing new distribution outlets, and by allowing such resource-rich firms to continually innovate to keep ahead of unchecked copying by rivals. The implication, therefore, is that providing emerging market firms with greater access to finance can open doors to their developing and commercializing more successful innovative new products. These suggestions certainly require additional empirical investigation.

On the other hand, in the UK, we find that innovativeness is most beneficial for new product success when markets are more dynamic. In the Ghanaian context, however, under high levels of environmental dynamism, greater innovativeness is less beneficial. One possible explanation is the fact that dynamism brings with it the need to reconfigure (i.e., change) the firm and its resources (e.g., finance and personnel) in order to address the evolving needs of customers and take on competitors (Greenley, 1995). Changing an organization necessitates flexibility and agility, requiring greater coordination efforts and responsibilities (Kogut and Zander, 1996). As a result, a firm's skills and capabilities in managing change may impact on the extent to which they benefit from greater innovation activities in dynamic market environment conditions. We suggest that unlike UK firms, firms in emerging markets like Ghana may suffer from an enhanced coordination burden arising from the need to respond rapidly to evolving and dynamic market environments. That is, emerging market firms may simultaneously lack the requisite skills and capabilities needed to effectively coordinate the changes required of them in dynamic environments, while at the same time becoming overstressed and disproportionately burdened by the challenges of achieving organizational change within the context of institutional voids (Panday, 2007). For example, the voids might affect firms' information dissemination activities and, even if firms are able to disseminate information about their new products, consumers may find it hard to access these new products because of underdeveloped distribution or infrastructure capabilities. As a result, networking activities in emerging markets are likely to be more important than simply reacting to market dynamics (London and Hart, 2004): when institutions fail informal social networks may become more powerful methods of learning 
about changes in market conditions (Sun et al., forthcoming). Again, our logic here requires further empirical investigation across larger numbers of developed and developing markets.

\subsection{Managerial and policy implications}

Our findings also have practical implications for doing business in developed and emerging markets. First, the findings indicate that beyond identifying an optimal level of product innovativeness, managers should consider rechanneling their resources to other customer value enhancing activities (such as cost reduction activities) to enhance new product success rates. Thus, managers in both developed and emerging markets should focus on determining and managing an optimal balance of novel and intensive product innovativeness that generates increases in new product success within the context of their unique institutional environments.

Second, we find that product innovation activities better enhance performance when marketoriented principles are strongly emphasized in both developed and emerging market firms. Thus, those firms that can invest more in their market orientation activities are better able to leverage their innovation activity. Interestingly, Kumar et al. (2011) observe that market orientation levels of businesses in developed markets are increasing in magnitude as the benefits of market-oriented activities are becoming more widely accepted as good business practice. Market orientation is also important in emerging markets. For local emerging market firms, market orientation capability helps leverage local market intelligence (London and Hart, 2004). To be able to compete with multinational giants flooding to emerging markets, local emerging market firms must seek to leverage local market knowledge, build local market capacity by means of developing relationships with customers, local suppliers and distributors. For multinational firms, we draw on London and Hart (2004) to suggest that the typical developed market learning approach may be insufficient when seeking to compete in emerging markets, and that these firms face challenges in gathering meaningful market information that is necessary to compete effectively with local emerging market firms ${ }^{3}$. Generating local emerging market insight may require them to use different approaches to channel partnerships that bridge the formal and informal economies (London and Hart, 2004), to localize R\&D more, and to develop stronger local informal networks (Ingenbleek et al., 2013). For emerging

\footnotetext{
${ }^{3}$ We thank the special issue editors, Professors Ernst Holger, Mohan Subramaniam, and Anna Dubiel for bringing this line of reasoning to our attention.
} 
market policy makers, there is likely to be a need to ensure that market orientation levels are increasing in the business population, and this may require investments in business education, where the principles of market oriented management can be ingrained in future entrepreneurs and business leaders from an early stage.

Third, the finding that the product innovativeness-performance relationship becomes more positive in Ghana when access to financial resources is stronger, but not in the UK, implies that emerging market firms may have different financial needs for ensuring the success of product innovation strategies. For developed market firms, finance can quite easily be accessed (due to strong financial institutions), and so access to finance is not a major determinant of innovation success: in these markets a more efficient use of financial resources may be a greater success factor. However, for emerging market firms, having greater access to finances does help to leverage the success of product innovation strategies. Certainly, for policy makers in emerging markets, there is an onus on creating conditions that enhance access to financial capital for firms actively engaged in innovation activities, as access to finance is a powerful moderator shaping the relationship between firm innovativeness and new product success. In highlighting the call by Juma (2010) to African nations to spark innovation-oriented growth, we suggest that policy initiatives that increase direct financing, matching grants, tax rebates and rewards to firms that innovate creatively and intensely will help increase successful new products from emerging markets.

Finally, the observation that, for Ghanaian firms, firm-level product innovativeness is less beneficial under higher levels of market dynamism is important, and suggests that managers operating in emerging markets must be extra careful as dynamism increases. Burdened by institutional voids at home, emerging market firms (unlike developed market counterparts) may be less capable of competing in more dynamic established market environments (Hart and Christensen, 2002). Given that emerging market firms may lack skills and capabilities required to reorganize to compete more effectively in a dynamic and hyper competitive markets, we suggest that emerging market firms require a competitive strategy that is premised on avoiding crowded high-end established markets dominated by well-resourced multinationals, and rather focus on taking the lead to first enter less established markets such as other emerging markets. For example, Chironga et al. (2011) argue that emerging African markets (unlike developed markets) offer great potential for growth because competition is low, consumer demand is increasing and innovation is 
less expensive to undertake. Thus, environmental dynamism is likely to be a growing issue for emerging markets. Given emerging market firms' strengths in developing new products that provide greater value to lower-end market segment, if an emerging market firm is experiencing increased dynamism in one market, we think that managers may need to weigh up the potential drawbacks that they face marketing increasingly sophisticated new products in such markets versus looking for alternative options in less dynamic markets to maximize return to innovation activities ${ }^{4}$. Alternatively, they will need to focus efforts on becoming more adept at keeping up with more agile developed-market counterparts.

\section{Limitations and Suggestions for Further Research}

From a theoretical point of view, this research has some limitations that need explaining. The study uses data from only one developed country and only one emerging market, and so generalizations beyond the countries discussed must be treated tentatively. While the UK is a major developed market, Ghana is probably not an obvious representative of an emerging market given its small size. That said, Ghana has similar socio-economic characteristics to other major emerging markets such as Brazil, China and India (Acquaah, 2007; Hoskisson et al., 2000). Future research, therefore, should be undertaken across a wider and more representative sample of developed and emerging market countries.

The study also focuses exclusively on new product performance as an outcome variable. However, future research could examine other dimensions of organizational performance such as overall firm financial success. Further research could also look into identifying determinants of firm-level product innovativeness, perhaps by examining organizational and external environment factors that foster or hinder greater integration of novel and intensive product innovativeness efforts in developed, as well as less developed markets.

Given our suggestion that increased institutional voids can dampen the chances of innovative products succeeding in emerging markets, compared to developed markets, we further argue that additional studies are needed to determine how differing levels of institutional development influence the impact of firm innovativeness on business success across developed and emerging markets. Beyond this, one could argue that environment dynamism affects performance outcomes of product innovativeness

\footnotetext{
${ }^{4}$ We again thank the special issue editors for suggesting this line of reasoning to us.
} 
differently across the UK and Ghanaian firms because Ghanaian firms may be operating in different sectors where the effect of dynamism is different from UK firms. We suggest that future research could help provide answers to this question.

On a related front, as one might expect, the UK firms are largely medium and large-sized businesses whereas the Ghanaian sample consists of mainly small and medium-sized firms. Although our analysis controls for firm size, future research should make efforts to sample similar groups of firms across developed and emerging markets. Similarly, while we control for industry type, the firms we study belong to different industries; hence, future research should focus on sampling firms in similar industrial sectors from developed and emerging market settings.

Finally, while a cross-sectional research design can provide an accurate snapshot of product innovation activities within firms, it could also be argued that a longitudinal study could help to increase the precision of the findings and enable stronger statistical inferences to be made. In this respect, we propose that future research studies examine the relationships across time.

\section{References}

Acquaah, M. 2007. Managerial social capital, strategic orientation, and organizational performance in an emerging economy. Strategic Management Journal 28: 1235-1255.

Aiken, L. S., and S. G. West. 1991. Multiple regression: Testing and interpreting interactions. Newbury Park, CA: Sage.

Akgün, A. E., H. Keskin, and J. Byrne. 2012. The role of organizational emotional memory on declarative and procedural memory and firm innovativeness. Journal of Product Innovation Management 29 (3): 432-451.

Arnold, D. J., and J. A. Quelch. 1998. New strategies in emerging markets. Sloan Management Review 40 (1): 7-20.

Atuahene-Gima, K., S. F. Slater, and E. M. Olson. 2005. The contingent value of responsive and proactive market orientations for new product program performance. Journal of Product Innovation Management 22: 464-482.

Bagozzi, R. P., and Y. Yi. 1988. On the evaluation of structural equation models. Journal of Academy of Marketing Science 16 (1): 74-94.

Baumol, W.J., Litan, R.E., and C.J. Schramm. (2009). Good capitalism, bad capitalism, and the economics of growth and prosperity. New Haven, CT: Yale University Press. 
Boso, N., J. W. Cadogan, and V. M. Story. 2012. Complementary effect of entrepreneurial and market orientations on export new product success under differing levels of competitive intensity and financial capital. International Business Review, 21(4): 667-681.

Bruton, G. D., D. Ahlstrom, and H. L. Li (2010). Institutional theory and entrepreneurship: Where are we now and where do we need to move in the future? Entrepreneurship Theory and Practice, 34(3): 421-440.

Cadogan, J. W., A. Diamantopoulos, and C. P. de Mortanges. 1999. A measure of export market orientation: Scale development and cross-cultural validation. Journal of International Business Studies 30 (4): 689-707.

Cadogan, J. W., N.J. Paul, R.T. Salminen, K. Puumalainen., and S. Sundqvist. (2001). Key antecedents to "export" market-oriented behaviors: a cross-national empirical examination. International Journal of Research in Marketing 18(3): 261-282.

Cadogan, J.W. 2010. Comparative, cross-cultural, and cross-national research: A comment on good and bad practice. International Marketing Review 27 (6): 601-605.

Calantone, R. J., R. Garcia, and C. Droge. 2003. The effects of environmental turbulence on new product development strategy planning. Journal of Product Innovation Management 20 (2): 90-103.

Calantone, R. J., T. S. Cavusgil, and Y. Zhao. 2002. Learning orientation, firm innovation capability and firm performance. Industrial Marketing Management 31: 515-524.

Cano, C.R., F.A. Carrillat, and F. Jaramillo. (2004). A meta-analysis of the relationship between market orientation and business performance: evidence from five continents. International Journal of research in Marketing 21(2): 179-200.

Cavusgil, T., P. Ghauri, and M. Agarwal. 2002. Doing business in emerging markets: Entry and negotiation strategies. Thousand Oaks: Sage.

Chatterjee, S. (1990). Excess resources, utilization costs, and mode of entry. Academy of Management Journal, 33 (4): 780-800.

Chironga, M., A., Leke, S. Lundand, A. van Wamelen. 2011. Cracking the next growth market: Africa. Harvard Business Review 89(5): 1-7.

Damanpour, F. 1991. Organisational innovation: A meta-analysis of effects of determinants and moderators. Academy of Management Journal 34: 555-590.

Danneels, E., and E. J. Kleinschmidt. 2001. Product innovativeness from the firm's perspective: Its dimensions and their relation with project selection and performance. Journal of Product Innovation Management 18 (6): 357-373.

De Luca, L. M., and K. Atuahene-Gima. 2007. Market knowledge dimensions and cross-functional collaboration: Examining the different routes to product innovation performance. Journal of Marketing 71: 95-112.

de Soto, H. 2000. The mystery of capital: Why capitalism triumphs in the West and fails everywhere else. New York: Basic Books. 
Deshpandé, R., A. Grinstein, S. H. Kim, and E. Ofek 2013. Achievement motivation, strategic orientations and business performance in entrepreneurial firms: How different are Japanese and American founders?. International Marketing Review 30(3): 231-252.

Deshpandé, R., and J. U. Farley. 2004. Organizational culture, market orientation, innovativeness and firm performance: An international research odyssey. International Journal of Research in Marketing 12: $3-22$.

Droge, C., R. Calantone, and N. Harmancioglu. 2008. New product success: Is it really controllable by managers in high turbulent environments? Journal of Product Innovation Management 25: 272-286.

Eweje, G. (2009). Labour relations and ethical dilemmas of extractive MNCs in Nigeria, South Africa and Zambia: 1950-2000. Journal of Business Ethics 86 (2): 207-223.

Fornell, C., and D. F. Larker. 1981. Evaluating structural equation models with unobservable variables and measurement error. Journal of Marketing Research 18 (1): 39-50.

Franke, G. R., and R. G. Richey. 2010. Improving generalizations from multi country comparisons in international business research. Journal of International Business Studies, 41(8), 1275-1293.

Gao, X., Zhang, P., and X. Liu. 2007. Competing with MNEs: Developing manufacturing capabilities or innovation capabilities. Journal of Technology Transfer32: 87-107.

Garcia, R., and R. Calantone. 2002. A critical look at technological innovation typology and innovativeness terminology: A literature review. Journal of Product Innovation Management 19 (2): $110-32$

Goedhuys, M., and L. Sleuwaegen. 2010. High-growth entrepreneurial firms in Africa: a quantile regression approach. Small Business Economics34(1): 31-51.

Greenley, G. E. 1995. Market orientation and company performance: empirical evidence from UK companies. British Journal of Management 6(1): 1-13.

Hansen, J.D., G.D., Deitz, M., Tokman, L. D., Marino, and K.M. Weaver. 2011. Cross national invariance of the entrepreneurial orientation scale. Journal of Business Venturing 26: 61-78.

Hart, S. L. 2010. Capitalism at the crossroads: Next generation business strategies for a post-crisis world. FT Press.

Hart, S. L., and C. M. Christensen. 2002. The great leap. Sloan Management Review 44(1): 51-56.

He, Z., and P. Wong. 2004. Exploration vs. exploitation: An empirical test of the ambidexterity hypothesis. Organization Science 15 (4): 481-494.

Hoegl, M., M., Gibbert, and D. Mazursky. 2008. Financial constraints in innovation projects: When is less more? Research Policy 37 (8): 1382-1391.

Horn, J. L., and J. J. McArdle. 1992. A practical and theoretical guide to measurement invariance in aging research. Experimental Aging Research 18: 117-144.

Hoskisson, R. E., L. Eden, C. M. Lau, and M. Wright. 2000. Strategy in emerging economies. Academy of Management Journal 43 (3): 249-267.

Howell, R. D., E. Breivik, and J. B. Wilcox. 2007. Reconsidering formative measurement. Psychological methods 12(2): 205-218. 
Hua, S. Y., and U. Wemmerlov. 2006. Product change intensity, product advantage, and market performance: An empirical investigation of the PC industry. Journal of Product Innovation Management 23: 316-329.

Hult, G. T. M., and D. J. Ketchen Jr. 2001. Does market orientation matter?: A test of the relationship between positional advantage and performance. Strategic Management Journal 22 (9): 899- 906.

Hult, G. T. M., R. F. Hurley, and G. A. Knight. 2004. Innovativeness: Its antecedents and impact on business performance. Industrial Marketing Management 33: 429-438.

Hurley, R. F., and G. T. M. Hult. 1998. Innovation, market orientation, and organizational learning: An integration and empirical examination. Journal of Marketing 62: 42-54.

Ingenbleek, P. T. M., W. K. Tessema, and H. C. M. van Trijp. 2013. Conducting field research in subsistence markets, with an application to market orientation in the context of Ethiopian pastoralists. International Journal of Research in Marketing 30 (1): 83-97.

Jaworski, B. J., and A. K. Kohli. 1993. Market orientation: Antecedents and consequences. Journal of Marketing 57: 53-70.

Joshi, A. W., and A. J. Campbell. 2003. Effect of environmental dynamism on relational governance in manufacturer-supplier relationships: a contingency framework and an empirical test. Journal of the Academy of Marketing Science 31(2): 176-188.

Juma, C. 2010. The new harvest: agricultural innovation in Africa. Oxford University Press.

Kirca, A. H., S. Jayachandran, and W.O. Bearden. (2005). Market orientation: a meta-analytic review and assessment of its antecedents and impact on performance. Journal of Marketing 69 (2): 24-41.

Kogut, B., and U. Zander. 1996. What firms do? Coordination, identity, and learning. Organization Science 7 (5): 502-518.

Kohli, A. K., and B. J. Jaworski. 1990. Market orientation: The construct, research propositions, and managerial implications. Journal of Marketing 54: 1-18.

Kumar, V., E., Jones, R., Venkatesan, and R.P. Leone. 2011. Is market orientation a source of sustainable competitive advantage or simply the cost of competing? Journal of Marketing 75(1): 16-30.

Kyrgidou L. P., and S. Spyropoulou. 2012. Drivers and performance outcomes of innovativeness: An empirical study. British Journal of Management DOI: 10.1111/j.1467-8551.2011.00803.x

Lado, N., and A. Maydeu-Olivares. 2001. Exploring the link between market orientation and innovation in the European and US insurance markets. International Marketing Review 18 (2): 130-145.

Lindell, M. K., and D. J. Whitney. 2001. Accounting for common method variance in cross-sectional research designs. Journal of Applied Psychology 86 (1): 114-121.

Little, T. D., J. A. Bovaird, and K. F. Widaman. 2006. On the merits of orthogonalizing powered and product terms: Implications for modeling interactions among latent variables. Structural Equation Modelling 13 (4): 497-519.

London, T., and S. L. Hart 2004. Reinventing strategies for emerging markets: beyond the transnational model. Journal of international business studies 35(5): 350-370. 
Lubatkin, M. H., Z. Simsek, Y. Ling, and J. F Veiga. 2006. Ambidexterity and Performance in Small- to Medium-Sized Firms: The Pivotal Role of Top Management Team Behavioral Integration. Journal of Management 32 (5): 646-672.

Luo, L., and R. L. Tung. 2007. International expansion of emerging market enterprises: A springboard perspective. Journal of International Business Studies 38: 481-498.

Luo, Y., J. Sun, and L. S. Wang. 2011. Emerging economy copycats: Capability, environment, and strategy. Academy of Management Perspectives 25: 37-56.

Manolova, T. S., R. V. Eunni, and B. S. Gyoshev. (2008). Institutional environments for entrepreneurship: evidence from emerging economies in Eastern Europe. Entrepreneurship: Theory and Practice 32 (1): 203-218.

Menguc, B., and S. Auh. 2006. Creating a firm-level dynamic capability through capitalizing on market orientation and innovativeness. Journal of the Academy of Marketing Science 341: 63-73.

Milgrom, P., and J. Roberts. 1994. Complementarities and systems: Understanding Japanese economic organization. Estudios Economicos 9: 3-42.

Miller, D., and P. H. Friesen. 1982. Innovation in conservative and entrepreneurial firms: Two models of strategic momentum. Strategic Management Journal 3 (1): 1-25.

Montoya-Weiss, M. M., and R. Calantone. 1994. Determinants of new product performance: A review and meta-analysis. Journal of Product Innovation Management 11 (4): 397-417.

Morgan, N. A., A. Kaleka, and C. S. Katsikeas. 2004. Antecedents of export venture performance: A theoretical model and empirical assessment. Journal of Marketing 68 (1): 90-108.

Özçelik, E. and E. Taymaz. 2004. Does innovativeness matter for international competitiveness in developing countries? The case of Turkish manufacturing industries. Research Policy, 33: 409-424.

Panday, P. K. 2007. Policy implementation in urban Bangladesh: role of intra-organizational coordination. Public Organization Review 7 (3): 237-259.

Paunov, C. 2012. The global crisis and firms' investments in innovation. Research Policy 41: 24-35.

Ping, R. A. Jr. 1995. A parsimonious estimation technique for interaction and quadratic latent variables. Journal of Marketing Research 32 (3): 336-347.

Podsakoff, P. M., S. B. MacKenzie, J-Y. Lee, and N. P. Podsakoff. 2003. Common method biases in behavioral research: A critical review of the literature and recommended remedies. Journal of Applied Psychology 88 (5): 879-903.

Reddy, P. 1997. New Trends in Globalization of Corporate R\&D and Implications for Innovation Capability in Host Countries: A Survey from India. World Development 25 (11): 1821-I 837.

Reddy, P., and Sigurdson, J. 1997. Strategic location of R\&D and emerging patterns of globalisation: the case of Astra Research Centre India. International Journal of Technology Management 14(2): 344361.

Roberts, P. W. 1999. Product innovation, product-market competition and persistent profitability in the U.S. pharmaceutical industry. Strategic Management Journal 20: 655-670. 
Rosenbusch, N., J. Brinckmann, and A. Bausch. 2011. Is innovation always beneficial? A meta-analysis of the relationship between innovation and performance in SMEs. Journal of Business Venturing 26 (4): 441-457.

Sandvik, I. L., and K. Sandvik. 2003. The impact of market orientation on product innovativeness and business performance. International Journal of Research in Marketing 20: 355-376.

Song, M., C. Droge, S. Hanvanich, and R. Calantone. (2005). Marketing and technology resource complementarity: an analysis of their interaction effect in two environmental contexts. Strategic Management Journal 26 (3): 259-276.

Steenkamp, J-B. E. M. and H. Baumgartner. 1998. Assessing measurement invariance in cross-national consumer research. Journal of Consumer Research 25 (1): 78-90.

Steenkamp, J-B. E. M., and K. Gielens. 2003. Consumer and market drivers of the trial probability of new consumer packaged goods. Journal of Consumer Research 29: 368-384.

Sun, S. L., and R. P. Lee. Forthcoming. Enhancing innovation through international joint venture portfolios: from the emerging firm perspective. Journal of International Marketing, doi :10.1509/jim.13.0016.

Szymanski, D. M., M. W. Kroff, and L. C. Troy. 2007. Innovativeness and new product success: Insights from cumulative evidence. Journal of the Academy of Marketing Science 35: 35-52.

Tajeddini, K., M. Trueman, and G. Larsen. 2006. Examining the effect of market orientation on innovativeness. Journal of Marketing Management 22: 529-551.

Tellis, G. J., J. C. Prahu, and R. K. Chandy. 2009. Radical innovation across nations: The preeminence of corporate culture. Journal of Marketing 73 (1): 3-23.

UNCTAD. 2012. World Investment Report 2005. United Nations, Geneva: unctad.org/en/PublicationsLibrary/wir2012_embargoed_en.pdf

Van Bruggen, G. H., G. L. Lilien, and M. Kacker. 2002. Informants in organizational marketing research: Why use multiple informants and how to aggregate responses. Journal of Marketing Research 34: 469-478.

van Waarden, F. 2001. Institutions and innovation: the legal environment of innovating firms. Organization Studies, 22 (5), 765-795.

Wang, C. L., and P. K. Ahmed. 2004. The development and validation of the organizational innovativeness construct using confirmatory factor analysis. European Journal of Innovation Management 7: 303-13.

Wiklund, J., and D. A. Shepherd. 2005. Entrepreneurial orientation and small business performance: A configurational approach. Journal of Business Venturing 20: 71-91.

Wiklund, J., and D. A. Shepherd. 2011. Where to from here? EO-as-experimentation, failure, and distribution of outcomes. Entrepreneurship: Theory \& Practice 35 (5): 925-946. 
Table 1: Firm and informant characteristics

\begin{tabular}{lrrrr}
\hline & \multicolumn{1}{c}{ UK } & \multicolumn{1}{c}{ Ghana } \\
\hline Firm characteristics & Mean & Standard Deviation & Mean & Standard Deviation \\
\hline Business experience (years) & 49.27 & 34.38 & 28 & 20 \\
Total employees & 10,872 & 28,249 & 15 & 9 \\
Total annual sales (US\$) & $78,420,792.74$ & $29,922,285.18$ & $300,200.00$ & $108,000.238$ \\
R\&D expenditure (\% of annual sales) & 15.43 & 16.71 & 39.80 & 22.85 \\
\hline Informant characteristics & & & & \\
\hline Managerial experience (years) & 26.25 & 8.34 & 15.59 & 8.17 \\
Knowledge of issues & 6.37 & .94 & 6.55 & .57 \\
Accuracy of information & 6.51 & .83 & 6.69 & .52 \\
Confidence in answers & 6.55 & .72 & 6.66 & .56 \\
\hline
\end{tabular}

Table 2: Descriptive characteristics and inter-construct correlations

\begin{tabular}{|c|c|c|c|c|c|c|c|c|c|c|c|c|}
\hline \multicolumn{13}{|c|}{ Panel A: UK and Ghana Samples } \\
\hline \multicolumn{2}{|c|}{ Variables } & 1. & 2. & 3. & 4. & 5. & 6. & 7. & 8. & 9. & 10. & 11. \\
\hline \multicolumn{2}{|c|}{ 1. Product innovation intensity } & & $.59^{* *}$ & $.90^{\text {*** }}$ & $.21^{* * *}$ & .05 & $.22^{* *}$ & $.34^{\text {*** }}$ & .08 & $.26^{* *}$ & $.28^{* * *}$ & .06 \\
\hline \multicolumn{2}{|c|}{ 2. Product innovation novelty } & $.55^{* * *}$ & & $.88^{* *}$ & $.24^{* *}$ & -.04 & $.21^{* *}$ & $.24^{* *}$ & .07 & $.24^{* *}$ & $.23^{* *}$ & .05 \\
\hline \multicolumn{2}{|c|}{ 3. Firm-level product innovativeness $\dagger$} & $.89 * *$ & $.87 * *$ & & $.26^{* *}$ & .01 & $.25^{* *}$ & $.33^{* *}$ & .09 & $.29^{* *}$ & $.29^{* *}$ & .04 \\
\hline \multicolumn{2}{|c|}{ 4. Financial resource } & $.23^{* *}$ & $.25^{* *}$ & $.27^{* * *}$ & & .09 & $.16^{*}$ & $.28^{* *}$ & .03 & $.21^{* *}$ & $.21^{* *}$ & .06 \\
\hline \multicolumn{2}{|l|}{ 5. Dynamism } & $.14^{* *}$ & $.15^{* *}$ & $.17^{\text {** }}$ & $.13^{*}$ & & $.14^{*}$ & .06 & -.01 & $.15^{*}$ & .07 & .07 \\
\hline \multicolumn{2}{|c|}{ 6. New product performance } & $.46^{* *}$ & $.42^{* *}$ & $.50^{* *}$ & $.28^{* *}$ & .10 & & $27^{* *}$ & .10 & $22^{* *}$ & $25^{* *}$ & .07 \\
\hline \multicolumn{2}{|c|}{ 7. Generation } & $.35^{* *}$ & $.24^{* *}$ & $.34^{* *}$ & $.28^{* *}$ & $.19^{* *}$ & $.43^{* *}$ & & .12 & $.52^{* *}$ & $.62^{* *}$ & -.00 \\
\hline \multicolumn{2}{|l|}{ 8. Dissemination } & $.19^{* *}$ & $.16^{* *}$ & $.21^{* *}$ & $.27^{* *}$ & $.11^{*}$ & $.42^{* *}$ & $.44^{* * *}$ & & .09 & $.77^{* *}$ & -.01 \\
\hline \multicolumn{2}{|l|}{ 9. Responsiveness } & $.38^{* *}$ & $.29^{* *}$ & $.39^{* *}$ & $.20^{* *}$ & $.25^{* *}$ & $.35^{* *}$ & $.55^{* *}$ & $.33^{* * *}$ & & $.63^{* *}$ & .11 \\
\hline \multicolumn{2}{|l|}{ 10.Market orientation $\dagger$} & $.39^{* *}$ & $29^{* *}$ & $.40^{* *}$ & $.32^{* *}$ & $.23^{* *}$ & $.50^{* *}$ & $.83^{* *}$ & $.73^{* *}$ & $.80^{* *}$ & & .04 \\
\hline \multicolumn{2}{|l|}{ 11.Marker variable $\ddagger$} & -.04 & .00 & -.02 & .01 & .01 & -.03 & -.01 & .07 & .03 & .04 & \\
\hline \multirow[t]{2}{*}{ Mean } & UK & 4.54 & 4.68 & 4.61 & 4.38 & 4.01 & 4.79 & 5.02 & 5.72 & 5.14 & 5.29 & 3.95 \\
\hline & Ghana & 4.47 & 4.57 & 4.52 & 4.30 & 4.07 & 4.80 & 5.01 & 4.59 & 5.10 & 4.90 & 4.40 \\
\hline \multirow[t]{2}{*}{ Standard Deviation } & UK & 1.12 & 1.02 & .94 & 1.15 & 1.34 & 1.18 & 1.01 & 1.02 & 1.12 & .83 & 1.72 \\
\hline & Ghana & 1.08 & 1.01 & .77 & 1.17 & 1.32 & 1.20 & .89 & 1.85 & 1.04 & .89 & 1.69 \\
\hline
\end{tabular}

\section{Panel B: Merged Sample}

1. Product innovation intensity

2. Product innovation novelty

$51^{* *}$

3. Firm-level product innovativeness $\uparrow .91^{* *} .85^{* * *}$

4. Financial resource $.19^{* *} .26^{* *} .25^{* *}$

5. Dynamism $\quad .13^{* *} .07 \quad .12^{* *} .11^{*}$

6. New product performance $\quad \begin{array}{llllll}\text { 6. } & .02 & .03 & .03 & .06 & .14^{* * *}\end{array}$

7. Generation

8. Dissemination

9. Responsiveness

10.Market orientation $\dagger$

$.27^{* *} .25^{* *} .30^{* *} .28^{* *} .15^{* *} .16^{* *}$

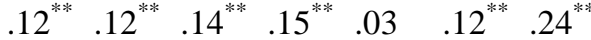

$.23^{* *} \quad .28^{* *} \quad .28^{* *} \quad .21^{* *} \quad .22^{* *} \quad .12^{* *} \quad .54^{* *} \quad .19^{* *}$

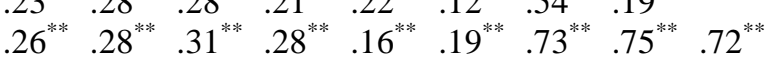

11.Marker variable

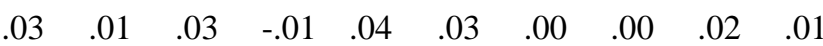

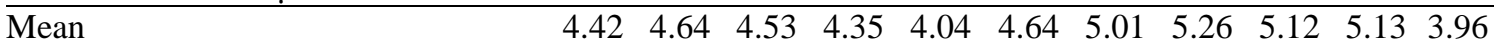

\begin{tabular}{llllllllllll} 
Standard Deviation & 1.33 & 1.02 & 1.03 & 1.16 & 1.33 & 1.00 & .97 & 1.59 & 1.08 & .87 & 1.71 \\
\hline
\end{tabular}

\section{Note:}

1. In Panel A, correlations for the UK sample appear in the lower-left half of the matrix, and correlations for the Ghanaian sample appear in the upperright half of the matrix.

2. $\dagger=$ Formative indices

3 . $t=$ We typically adopt an undo-the-competitor posture in our target markets

4. $*<.05$

$5 . * *<.01$ 
Table 3: Measurement invariance tests

\begin{tabular}{lrrrrrr}
\hline \multicolumn{6}{l}{ Panel A: An example of test procedure: Firm-level product innovation intensity across UK and Ghanaian firms } \\
\hline Models & $\chi^{\mathbf{2}}$ (d.f.) & p-value & RMSEA & NNFI & CFI & CAIC \\
\hline Configural invariance & $.00(0)$ & .00 & .00 & 1.00 & 1.00 & NA \\
Metric invariance & $.64(2)$ & .73 & .00 & 1.00 & 1.00 & 117.30 \\
Scalar invariance & $2.40(5)$ & .79 & .01 & 1.00 & 1.00 & 97.17 \\
Factor variance invariance & $2.41(6)$ & .88 & .01 & 1.00 & 1.00 & 89.90 \\
Error variance invariance & $3.32(9)$ & .95 & .01 & 1.00 & 1.00 & 68.95
\end{tabular}

Panel B: Tests of key constructs across UK versus Ghana firms

\begin{tabular}{|c|c|c|c|c|c|}
\hline & \multicolumn{5}{|c|}{$\chi^{2}$ difference tests } \\
\hline & Configural & $\begin{array}{l}\text { Metric versus } \\
\text { configural }\end{array}$ & $\begin{array}{l}\text { Scalar versus } \\
\text { metric }\end{array}$ & $\begin{array}{l}\text { Factor variance } \\
\text { versus scalar }\end{array}$ & $\begin{array}{l}\text { Error variance } \\
\text { versus factor } \\
\text { variance }\end{array}$ \\
\hline $\begin{array}{l}\text { Firm-level product } \\
\text { innovation intensity }\end{array}$ & $\begin{array}{l}\chi^{2}=.00(0) \\
\mathrm{p}=1.00\end{array}$ & $\begin{array}{l}\Delta \chi^{2}(2)=.64 \\
p=.73\end{array}$ & $\begin{array}{l}\Delta \chi^{2}(3)=1.74 \\
\mathrm{p}=.63\end{array}$ & $\begin{array}{l}\Delta \chi^{2}(1)=.03 \\
p=.86\end{array}$ & $\begin{array}{l}\Delta \chi^{2}(3)=.91 \\
\mathrm{p}=.82\end{array}$ \\
\hline $\begin{array}{l}\text { Firm-level product } \\
\text { innovation novelty }\end{array}$ & $\begin{array}{l}\chi^{2}=.00(0) \\
p=1.00\end{array}$ & $\begin{array}{l}\Delta \chi^{2}(2)=1.73 \\
\mathrm{p}=.42\end{array}$ & $\begin{array}{l}\Delta \chi^{2}(3)=1.72 \\
\mathrm{p}=.63\end{array}$ & $\begin{array}{l}\Delta \chi^{2}(1)=.05 \\
\mathrm{p}=.82\end{array}$ & $\begin{array}{l}\Delta \chi^{2}(3)=3.49 \\
p=.32\end{array}$ \\
\hline Financial resource & $\begin{array}{l}\chi^{2}=15.31(4) \\
p=.00\end{array}$ & $\begin{array}{l}\Delta \chi^{2}(3)=0.82 \\
\mathrm{p}=.84\end{array}$ & $\begin{array}{l}\Delta \chi^{2}(1)=3.72 \\
\mathrm{p}=.16\end{array}$ & $\begin{array}{l}\Delta \chi^{2}(1)=3.72 \\
\mathrm{p}=.16\end{array}$ & $\begin{array}{l}\Delta \chi^{2}(5)=9.58 \\
p=.09\end{array}$ \\
\hline Environment dynamism & $\begin{array}{l}\chi^{2}=.00(0) \\
p=1.00\end{array}$ & $\begin{array}{l}\Delta \chi^{2}(2)=0.67 \\
\mathrm{p}=.72\end{array}$ & $\begin{array}{l}\Delta \chi^{2}(3)=.15 \\
p=.99\end{array}$ & $\begin{array}{l}\Delta \chi^{2}(1)=.03 \\
p=.86\end{array}$ & $\begin{array}{l}\Delta \chi^{2}(3)=.87 \\
\mathrm{p}=.85\end{array}$ \\
\hline New product performance & $\begin{array}{l}\chi^{2}=26.68(14) \\
p=.00\end{array}$ & $\begin{array}{l}\Delta \chi^{2}(3)=0.46 \\
p=.92\end{array}$ & $\begin{array}{l}\Delta \chi^{2}(7)=1.03 \\
\mathrm{p}=.99\end{array}$ & $\begin{array}{l}\Delta \chi^{2}(7)=1.03 \\
\mathrm{p}=.99\end{array}$ & $\begin{array}{l}\Delta \chi^{2}(11)=1.56 \\
\mathrm{p}=.99\end{array}$ \\
\hline Generation & $\begin{array}{l}\chi^{2}=54.55(30) \\
p=.00\end{array}$ & $\begin{array}{l}\Delta \chi^{2}(4)=1.77 \\
p=.78\end{array}$ & $\begin{array}{l}\Delta \chi^{2}(9)=3.36 \\
\mathrm{p}=.94\end{array}$ & $\begin{array}{l}\Delta \chi^{2}(9)=3.36 \\
\mathrm{p}=.94\end{array}$ & $\begin{array}{l}\Delta \chi^{2}(14)=16.83 \\
p=.27\end{array}$ \\
\hline Dissemination & $\begin{array}{l}\chi^{2}=29.69(14) \\
p=.00\end{array}$ & $\begin{array}{l}\Delta \chi^{2}(3)=4.78 \\
p=.19\end{array}$ & $\begin{array}{l}\Delta \chi^{2}(7)=5.25 \\
\mathrm{p}=.63\end{array}$ & $\begin{array}{l}\Delta \chi^{2}(7)=5.25 \\
\mathrm{p}=.63\end{array}$ & $\begin{array}{l}\Delta \chi^{2}(9)=7.46 \\
\mathrm{p}=.59\end{array}$ \\
\hline Responsiveness & $\begin{array}{l}\chi^{2}=.00(0) \\
p=1.00\end{array}$ & $\begin{array}{l}\Delta \chi^{2}(2)=.96 \\
p=.62\end{array}$ & $\begin{array}{l}\Delta \chi^{2}(3)=1.40 \\
\mathrm{p}=.71\end{array}$ & $\begin{array}{l}\Delta \chi^{2}(1)=2.97 \\
\mathrm{p}=.08\end{array}$ & $\begin{array}{l}\Delta \chi^{2}(9)=10.71 \\
\mathrm{p}=.28\end{array}$ \\
\hline
\end{tabular}

Note: Chi-square statistic $\left(\chi^{2}\right)$; Degrees of freedom (D.F.); Consistent Akaike information criterion (CAIC); comparative fit index (CFI); Non-normed fit index (NNFI); and root mean square error of approximation (RMSEA); NA (Not Applicable). 
Table 4: Comparison of Estimated Structural Models

\begin{tabular}{|c|c|c|c|c|c|c|c|c|c|}
\hline \multirow[b]{2}{*}{ Models } & \multirow[b]{2}{*}{$\chi^{2}$ (d.f.) } & \multirow[b]{2}{*}{ p-value } & \multirow[b]{2}{*}{$\Delta \chi^{2}$ (d.f.) } & \multirow[b]{2}{*}{ RMSEA } & \multirow[b]{2}{*}{ NNFI } & \multirow[b]{2}{*}{ CFI } & \multicolumn{2}{|c|}{$\mathbf{R}^{2}$} & \multirow[b]{2}{*}{ CAIC } \\
\hline & & & & & & & UK & $\mathbf{G}$ & \\
\hline Model 1 & $123.99(81)$ & .01 & & .04 & .96 & .99 & .40 & .18 & 2289.59 \\
\hline Model 2 & $85.59(70)$ & .09 & $38.40(11)^{\mathrm{A}}$ & .03 & .98 & .99 & .47 & .25 & 2331.18 \\
\hline Model 3 & 90.85 (77) & .13 & $5.26(7)^{\mathrm{B}}$ & .03 & .99 & .99 & .45 & .23 & 2295.62 \\
\hline Model 4 & $77.09(73)$ & .35 & $8.5(3)^{\mathrm{C}}$ & .01 & .99 & 1.00 & .59 & .31 & 2301.02 \\
\hline Model 5 & $78.08(74)$ & .35 & $1.01(1)^{\mathrm{D}}$ & .01 & .99 & 1.00 & .59 & .31 & 2294.72 \\
\hline Model 6 & $78.18(74)$ & .35 & $1.09(1)^{\mathrm{E}}$ & .02 & .99 & 1.00 & .59 & .31 & 2294.82 \\
\hline Model 7 & $87.47(74)$ & .14 & $10.38(1)^{\mathrm{F}}$ & .03 & .99 & 1.00 & .57 & .30 & 2304.10 \\
\hline Model 8 & $88.07(74)$ & .14 & $10.98(1)^{\mathrm{G}}$ & .03 & .98 & .99 & .57 & .30 & 2297.42 \\
\hline Model 9 & $80.49(75)$ & .31 & $3.40(2)^{\mathrm{H}}$ & .02 & .99 & 1.00 & .60 & .31 & 2289.83 \\
\hline
\end{tabular}

UK: United Kingdom

G: Ghana

Model 1: Hypothesized paths fixed at zero; all remaining paths set invariant across both countries.

Model 2: Hypothesized paths fixed at zero; all remaining paths allowed to vary across both countries.

Model 3: Hypothesized paths allowed to take on non-zero values, but are set invariant across both countries; all remaining paths set invariant across both countries.

Model 4: Hypothesized paths allowed to take on non-zero values, but are allowed to vary across both countries; all remaining paths set invariant across both countries.

Model 5: Model 4 re-estimated, but PI-squared is set invariant across both countries.

Model 6: Model 4 re-estimated, but PI-squared x MO is set invariant across both countries.

Model 7: Model 4 re-estimated, but PI-Squared x FIN is set invariant across both countries.

Model 8: Model 4 re-estimated, but PI-squared x DYN is set invariant across both countries.

Model 9: Model 4 re-estimated, but with both PI-squared and PI-squared x MO set invariant across both countries.

A: Relative to Model 1, decrease in Chi-square on moving to Model 2 is significant at $1 \%$.

B: Relative to Model 2, increase in Chi-square on moving to Model 3 is not significant.

C: Relative to Model 2, decrease in Chi-square on moving to Model 4 is significant at $5 \%$.

D: Relative to Model 4, increase in Chi-square on moving to Model 5 is not significant.

E: Relative to Model 4, increase in Chi-square on moving to Model 6 is not significant.

F: Relative to Model 4, increase in Chi-square on moving to Model 7 is significant at $1 \%$.

G: Relative to Model 4, increase in Chi-square on moving to Model 8 is significant at $1 \%$.

H: Relative to Model 4, increase in Chi-square on moving to Model 9 is not significant.

Table 5: Model Standardized Path Estimates and T-values ${ }^{\mathrm{A}}$

\begin{tabular}{lrrrrr}
\hline & \multicolumn{5}{c}{ Dependent variable: } \\
Variables \& Hypotheses & \multicolumn{7}{c}{ Restricted model $^{\mathbf{B}}$} & \multicolumn{2}{c}{ Unrestricted model } & \multicolumn{1}{c}{$\Delta$ results } \\
\cline { 2 - 6 } Control paths: & \multicolumn{1}{c}{ UK } & \multicolumn{1}{c}{ Ghana } & UK & \multicolumn{1}{c}{ Ghana } & UK vs. Ghana \\
\cline { 2 - 6 } Industry dummy & & & & & \\
Business experience & $-.05(-1.06)$ & $.06(1.00)$ & $-.01(-.42)$ & $-.01(-.42)$ & invariant \\
R\&D expenditure & $-.10(-1.25)$ & $-.02(-.52)$ & $-.04(-1.17)$ & $-.04(-1.17)$ & invariant \\
Firm size & $-.03(-.52)$ & $-.04(-.82)$ & $-.03(-.77)$ & $-.03(-.77)$ & invariant \\
Financial resource (FIN) & $-.07(-1.56)$ & $-.10(-1.52)$ & $-.08(2.06)$ & $-.08(2.06)$ & invariant \\
Market orientation (MO) & $.09(1.92)$ & $.04(.64)$ & $.04(1.05)$ & $.04(1.05)$ & invariant \\
Environmental dynamism (DYN) & $.37(7.22)$ & $.14(2.22)$ & $.28(6.90)$ & $.28(6.90)$ & invariant \\
Firm-level product innovativeness (PI) & $-.02(-.37)$ & $.09(1.51)$ & $.03(.70)$ & $.03(.70)$ & invariant \\
PI x FIN & $.40(7.32)$ & $.24(3.48)$ & $.27(6.11)$ & $.27(6.11)$ & invariant \\
PI x MO & $.08(1.65)$ & $.02(.29)$ & $.06(1.37)$ & $.06(1.37)$ & invariant \\
PI x DYN & $.03(.71)$ & $.04(.39)$ & $.24(6.00)$ & $.24(6.00)$ & invariant \\
Hypothesized paths: & $-.07(-1.38)$ & $.58(5.82$ & $-.09(-2.06)$ & $-.09(-2.06)$ & invariant \\
H1: PI-squared & & & & & \\
H2: PI-squared x MO & & & $-.24(-4.25)$ & $-.24(-4.25)$ & invariant \\
H3a \& H3b: PI-Squared x FIN & & & $.22(4.63)$ & $.22(4.63)$ & invariant \\
H4a \& H4b: PI-squared x DYN & & & $.10(1.38)$ & $.16(1.69)$ & variant \\
\hline
\end{tabular}

A: T-values are in parenthesis: critical t-values for hypothesized paths $=1.645$ (5\%, one-tail tests).

B: Results from Model 2 in Table 4: Hypothesized paths fixed at zero: all remaining paths allowed to vary across both countries.

C: Results from Model 9 in Table 4: Hypothesized paths allowed to take on non-zero values, PI-squared x FIN and PI-squared x DYN allowed to vary across the countries, and all remaining paths set invariant across the countries. 
Figure 1: Conceptual model and hypotheses

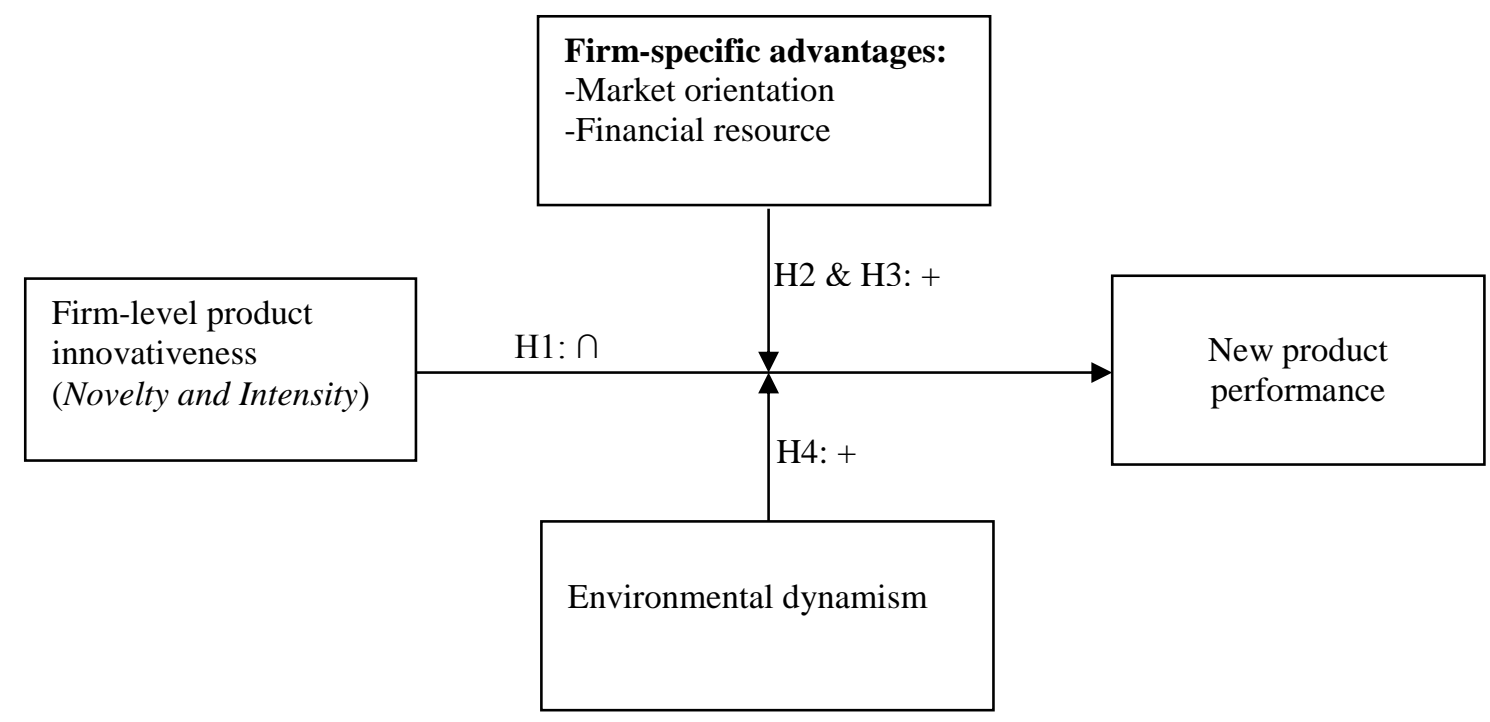

Figure 2: Pure Quadratic Effects of Firm-level Product Innovativeness

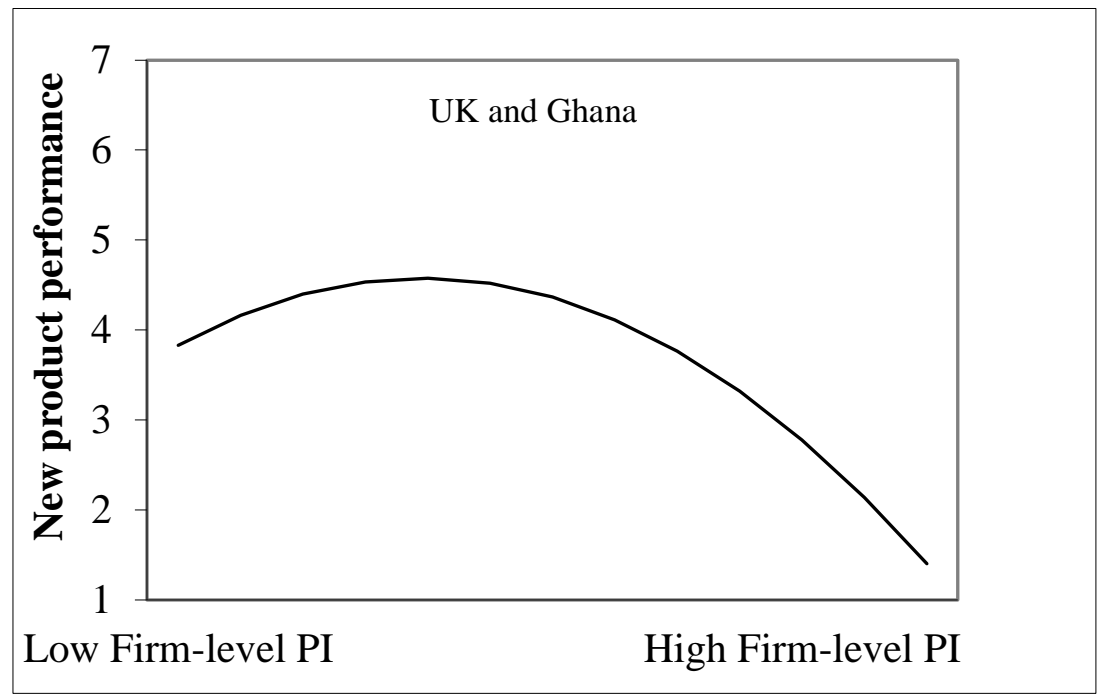

PI: Product Innovativeness

Figure 3(A): Interaction Effects of Market Orientation

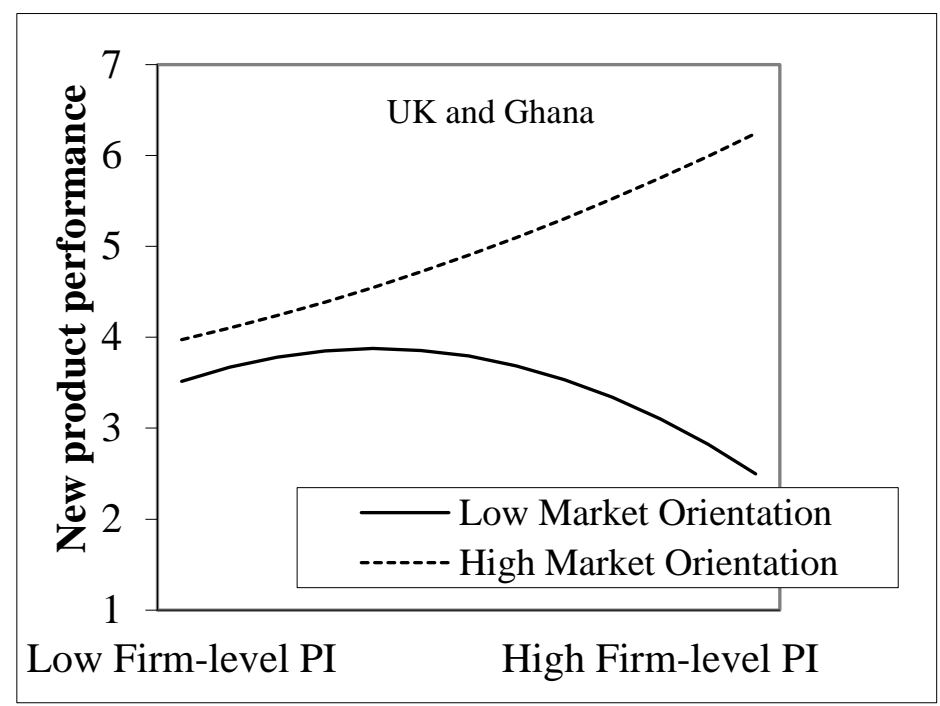


Figure 3(B): Interaction Effects of Financial Resources

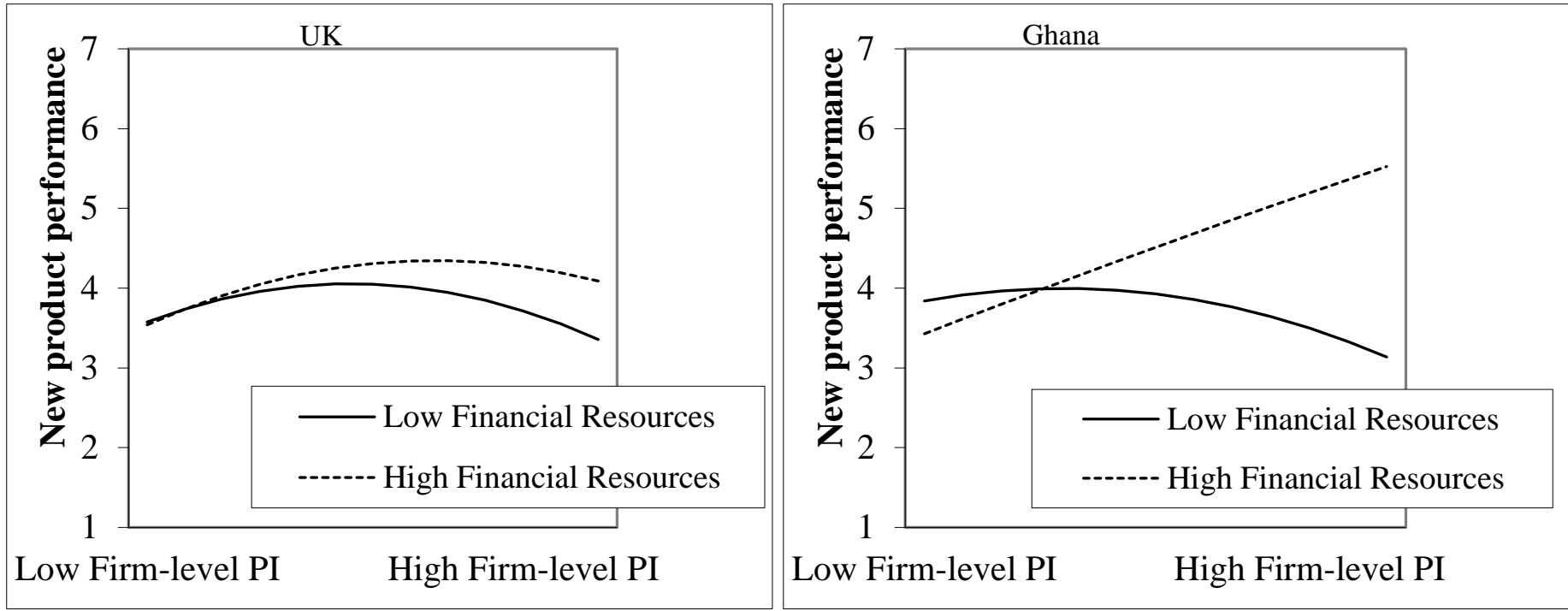

Figure 3(C): Interaction Effects of Environmental Dynamism
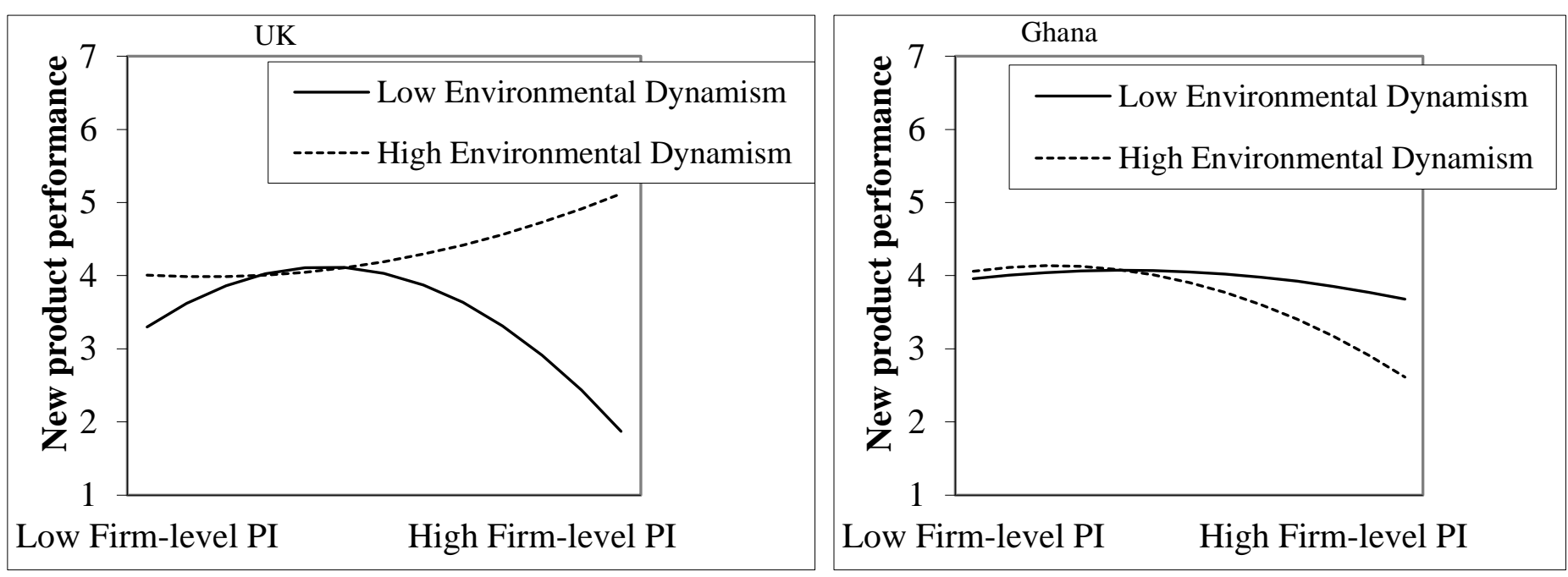
Appendix

Details of measures, results of validity tests

\section{Standardized factor}

Measure details

Product innovation intensity $(1=$ not at all; $7=$ to an extreme extent $)$ : CR $=.91 ; \mathrm{AVE}=.78 ; \mathrm{HSV}=.26$

-On average, each year we introduce more new products /services in our target markets than our key target market competitors

-Industry experts would say that we are more prolific when it comes to introducing new products/services in our target markets

-Our key target market competitors cannot keep up with the rate at which we introduce new products/services in our target markets

Product innovation novelty $(1=$ not at all; $7=$ to an extreme extent $): \mathrm{CR}=.86 ; \mathrm{AVE}=.67 ; \mathrm{HSV}=.07$

-Relative to our main competitors, the products/services we offer in our target market(s) are radical

-Relative to our main competitors, the products/services we offer in our target market(s) are creative

-Relative to our main competitors, the products/services we offer in our target market(s) are inventive

Financial resource $(1=$ not at all; $7=$ to an extreme extent $): \mathrm{CR}=.86 ; \mathrm{AVE}=.61 ; \mathrm{HSV}=.02$

-Our company has easy access to financial capital to support its business operations

-If we need more financial assistance for our business operations, we could easily get it

-We have substantial financial resources at the discretion of managers for funding business initiatives

-We are able to obtain financial resources at short notice to support business operations

Environment dynamism ( $1=$ not at all; $7=$ to an extreme extent $)$ : $\mathrm{CR}=.81 ; \mathrm{AVE}=.58 ; \mathrm{HSV}=.12$

-Competitors are constantly trying out new competitive strategies

-Customer needs and demands are changing rapidly in our industry

-New markets are emerging for products and services in our industry

loadings

UK

Ghana

$.88(1.00)$
$.88(27.10)$

$.88(27.10)$
$.87(26.71)$

$.78(1.00)$

$.87(23.19)$

$.80(20.79)$

$.73(1.00)$

$.77(16.48)$

$.82(17.29)$

.80 (16.95)

$.66(1.00)$

$.75(14.76)$

$.86(15.96)$
$.88(1.00)$

$.87(26.71)$

$.78(1.00)$

$.87(23.19)$

$.80(20.79)$

$.73(1.00)$

.77 (16.48)

$.82(17.29)$

.80 (16.95)

$.66(1.00)$

.75 (14.76)

$.86(15.96)$

0.43

$0.26(8.84)$

.47 (13.37)

$.41(12.42)$

$.33(10.91)$

.36 (11.66)
$.88(27.10)$

Error variances

UK

Ghana

New product performance $(1=$ below expectation; $7=$ exceeded expectation $)$ : $\mathrm{CR}=.86 ; \mathrm{AVE}=.60 ; \mathrm{HSV}=.03$

Compared with your business objectives, how well have you performed on each of the following indicators during the previous three years?

-revenues from new products or services

-growth in revenue from new products or services

-growth in sales of new products or services

-profitability of new products or services

$\begin{array}{rrrr}.69(1.00) & .69(1.00) & .52(14.06) & .52(14.06) \\ .75(15.48) & .75(15.48) & .43(13.01) & .43(13.01) \\ .87(17.05) & .87(17.05) & .25(8.66) & .25(8.66) \\ .78(15.96) & .78(15.96) & .39(12.30) & .39(12.30)\end{array}$


Details of measures, results of validity tests (continued)

Measure details

Standardized factor loadings

Intelligence Generation ( $1=$ strongly disagree; $7=$ strongly agree): $\mathrm{CR}=.82 ; \mathrm{AVE}=.53 ; \mathrm{HSV}=0.06$

-we generate a lot of information concerning trends (e.g., regulations, technological developments, political, economic) in our target market markets

-we constantly monitor our level of commitment and orientation to serving customer needs

-we are fast to detect fundamental shifts in our target market environment (e.g., regulation, technology, economy)

-we periodically review the likely effect of changes in our target market environment (e.g., regulations, technology)

UK Ghan

$\begin{array}{rrrr}.73(1.00) & .73(1.00) & .47(12.90) & .47(12.90) \\ .71(14.90) & .71(14.90) & .50(13.40) & .50(13.40) \\ .64(13.67) & .64(13.67) & .58(14.12) & .58(14.12) \\ .82(16.75) & .82(16.75) & .33(10.36) & .33(10.36) \\ & & & \\ .84(1.00) & .84(1.00) & .29(14.04) & .29(14.04) \\ .94(29.87) & .94(29.87) & .12(9.54) & .12(9.54) \\ .91(28.23) & .91(28.23) & .18(11.85) & .18(11.85) \\ & & & \\ .87(26.29) & .87(26.29) & .24(13.37) & .24(13.37) \\ & & & \\ .68(1.00) & .68(1.00) & .54(13.72) & .54(13.72) \\ .81(15.37) & .81(15.37) & .34(9.97) & .34(9.97) \\ .83(15.48) & .83(15.48) & .31(9.22) & .31(9.22)\end{array}$

$.83(15.48)$

$.83(15.48)$

Intelligence Dissemination ( $1=$ strongly disagree; $7=$ strongly agree $)$ : $\mathrm{CR}=.94 ; \mathrm{AVE}=.79 ; \mathrm{HSV}=.30$

-too much information concerning our competitors is discarded before it reaches

-information that can influence the way we serve our customers takes forever to reach relevant personnel

-important information about our customers is often 'lost in the system'

-important information concerning target market trends (e.g. regulation, technology) is often discarded as it makes its way along

the communication chain

Intelligence Responsiveness $(1=$ strongly disagree; $7=$ strongly agree $): \mathrm{CR}=.82 ; \mathrm{AVE}=.60 ; \mathrm{HSV}=0.08$

-we are quick to respond to important changes in our business environment (e.g., regulation, technology)

-we are quick to respond to significant changes in our competitors' price structures in target markets

Error variances

-we rapidly respond to competitive actions that threaten us in our target markets

Note: t-values are in parentheses; $\mathrm{CR}=$ construct reliability; AVE = average variance extracted; HSV = highest shared variance with other constructs 